\title{
Regional dynamical downscaling over West Africa: model evaluation and comparison of wet and dry years
}

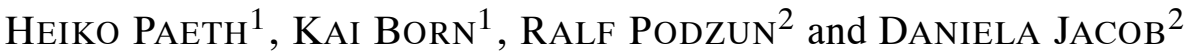 \\ ${ }^{1}$ Meteorological Institute, University of Bonn, Germany \\ ${ }^{2}$ Max-Planck-Institute for Meteorology, Hamburg, Germany
}

(Manuscript received February 2, 2005; in revised form May 2, 2005; accepted May 10, 2005)

\begin{abstract}
In this study, a 25-year regional climate model run over West Africa is evaluated and examined with respect to causes of interannual rainfall variability related to the West African Monsoon. West African rainfall has been subject to strong interannual and decadal variability throughout the past 50 years. Known driving forces for this variability are large-scale changes in Atlantic sea surface temperatures (SSTs), variability due to global atmospheric circulation changes, like for instance variability related to El Niño-Southern Oscillation, but also regional and local-scale changes in land use and vegetation cover. The interaction of these impact factors with West African synoptic and subsynoptic processes is still not completely understood. One reason for this lack of knowledge is that basic features of West African climate, including the African Easterly Jet (AEJ), African Easterly Waves (AEWs) as well as monsoon dynamics, are very complex multiscale phenomena. Climate modeling in West Africa requires the ability to simulate these effects, which can only be achieved by mesoscale atmospheric models. Using the regional climate model REMO from the Max-Planck Institute for Meteorology in Hamburg, a 25-year dynamical downscaling study was undertaken in order to evaluate a tool, which will then be used for the examination of causes of rainfall variability in West Africa. The model was used on a $0.5^{\circ}$ grid over North Africa northward of $15^{\circ} \mathrm{S}$. The model evaluation leads to some confidence in the reliability of the modeled climate. A detailed examination of composites of selected wet and dry years in the Guinean coast region elucidates the role of SST forcing and external atmospheric forcing for interannual rainfall variability. In general, abundant monsoonal rainfall comes along with warm tropical Atlantic SSTs, enhanced latent heat fluxes from the ocean to the atmosphere and stronger surface wind convergence near the Guinean Coast. This is accompanied by large-scale dynamical changes in strength and direction of both the Tropical Easterly Jet (TEJ) over the Indian Ocean and the Subtropical Jet (STJ) over the Near East and the Caucasian region.
\end{abstract}

\section{Zusammenfassung}

In dieser Studie wird eine 25-jährige Klimasimulation mit einem regionalen Klimamodell im westafrikanischen Sektor evaluiert und im Hinblick auf die Einflussgrös̈en interannueller Niederschlagsvarabilität im westafrikanischen Monsungebiet untersucht. Der Niederschlag im westlichen Afrika war während der letzten 50 Jahre durch starke interannuelle und dekadische Schwankungen gekennzeichnet. Zu den vermuteten Antriebsmechanismen für die Klimavariabilität zählen die gros̈skaligen Fluktuationen der Meeresoberflächentemperaturen (SSTs) im Atlantik, Schwankungen der globalen atmosphärischen Zirkulation wie zum Beispiel im Zusammenhang mit El Niño-Southern Oscillation sowie regionale und lokale Veränderungen in der Landnutzung und Vegetationsbedeckung. Bislang sind die Interaktionen zwischen diesen Antriebsfaktoren und synoptischen sowie subsynoptischen Prozessen in Westafrika kaum verstanden. Das liegt unter anderem darin begründet, dass die grundlegenden Ausprägungen des westafrikanischen Klimas wie der African Easterly Jet (AEJ), die African Easterly Waves (AEWs) und das Monsunsystem sehr komplexe multiskalige Phänomene darstellen. Klimamodelle sind gefordert, diese Phänomene und ihre Auswirkungen zu simulieren. Dies kann nur von mesoskaligen Modellen erreicht werden. Auf der Basis des regionalen Klimamodells REMO vom Max-Planck-Institut für Meteorologie in Hamburg wurde eine 25-jährige Downscaling-Studie durchgeführt. Damit steht nun ein Werkzeug zur Verfügung, um die Einflussfaktoren der Niederschlagsvariabilität in Westafrika zu untersuchen. Die Modellsimulation umfä̈t den afrikanischen Kontinent nördlich von $15^{\circ} \mathrm{S}$ in einer horizontalen Auflösung von $0,5^{\circ}$. Die Validation mit diversen Beobachtungsdaten zeigt, dass das regionale Klimamodell die grundlegenden Strukturen des westafrikanischen Klimas sehr zuverlässig reproduzieren kann. Eine detaillierte Untersuchung der Composites ausgewählter feuchter und trockener Monsunjahre untermauert die besondere Rolle des SST-Antriebes und der atmosphärischen Randbedingungen für die interannuellen Niederschlagsschwankungen. Reichhaltige Monsunniederschläge gehen allgemein mit wärmeren SSTs im tropischen Atlantik sowie verstärkten latenten Wärmeflüssen und bodennaher Windkonvergenz an der Guineaküste einher. Darüber hinaus ergeben sich Veränderungen in der gros̈räumigen Zirkulation, wovon insbesondere der Tropical Easterly Jet (TEJ) über dem Indischen Ozean und der subtropische Jet (STJ) über dem Nahen Osten und der Kaukasusregion betroffen sind.

${ }^{*}$ Corresponding author: Heiko Paeth, Meteorologisches Institut, Universität Bonn, Auf dem Hügel 20, 53121 Bonn, Germany, e-mail: hpaeth@uni-bonn.de 


\section{Introduction}

Large parts of the West African subcontinent are characterized by a low natural potential mainly due to limited freshwater availability. Particularly, in the subsaharan region including the Sahel, the Sudan and the tropical Guinean Coast line, highly sensitive ecosystems and fragile vegetation cover are confronted with one of the world's highest population growth rates, intensive agriculture and exploiting pastural systems (WANG and ELTAHIR, 2000; SAHA and SAHA, 2001; CLARK et al., 2001).

Since the 1970s, this part of the world is subject to remarkable droughts. In the 1980s, the driest period throughout the 20th century was observed (NICHOLSON et al., 2000; Hulme et al., 2001; LE BARBÉ et al., 2002). It caused wide-ranging socio-economic implications for food production, human welfare and political stability (BENSON and CLAY, 1998). This dramatic deterioration of life conditions has resulted in an increase of scientific attention with the aim of understanding the causes of continuing drought years. Two major hypotheses have been postulated (WANG and ELTAHIR, 2000): (1) The drought comes along with a fundamental change of the global sea surface temperature (SST) pattern (CHANG et al., 2000; VIZY and COOK, 2001; Nicholson, 2001; GiAnNini et al., 2003; PAETH and HENSE, 2004). (2) It is induced by a more direct anthropogenic impact in the form of land use changes, affecting vegetation cover (BOUNOUA et al., 2000; WANG and Eltahir, 2000; ZENG and NEELIN, 2000; ClARK et al., 2001; SEMAZZI and SONG, 2001), surface albedo and soil moisture (Douville and CHAUVIN, 2000; Douville, 2002). Nicholson (2001) and ZENG et al. (1999) suggest that rainfall anomalies over subsaharan West Africa are primarily triggered by SST changes and secondarily enhanced in amplitude and period by local feedbacks with vegetation, surface albedo and soil moisture.

West Africa is also subject to some speculation with respect to climate change because observations in the late 1990s indicate a slight recovery in annual rainfall (NiCOLSON et al., 2000). Future climate change simulations predict an increase of rainfall over the Guinean coastal region and a decrease over the Sahel (HuLME et al., 2001; PAeth and Hense, 2004) under rising greenhouse gas (GHG) concentrations.

In order to supply a scientific basis for political decisions, agricultural planning and hydrological measures, it is strictly required to understand the physical mechanisms influencing climate variability over West Africa, and to quantify the relative contributions of various impact factors like SST, GHGs and land cover characteristics. These issues can only be accounted for by means of climate model simulations, producing reliable high-resolution data sets in regions with low observational data coverage and carrying out sensitivity studies with respect to the various external factors. However, simulating the main features of West African climate is a great challenge for state-of-the-art climate models (JENKINS et al., 2002): Elements of West African weather and climate are very complex with many spatiotemporal scales interacting with each other (LONG et al., 2000; SAHA and SAHA, 2001, 2002). Large-scale tropical phenomena like El Niño-Southern Oscillation (ENSO) (HASTENRATH, 2000; NichOlson and SELATO, 2000; JANICOT et al., 2001) and extratropical circulation like the North Atlantic Oscillation (CULLEN and DE MENOCAL, 2000; LOS et al. 2001), SST, orographic effects, differential surface heating, adiabatic processes and interactions with local land surface parameters are involved in generating wind systems like the African Easterly Jet (AEJ) (COOK, 1999; HASTENRATH, 2000; GRIST and NICHOLSON, 2001; NICHOLSON and GRIST, 2001), the African Easterly Waves (AEWs) (DRUYAN et al., 2000; DIEDHIOU et al., 2001; THORNCROFT and Hodges, 2001; GRIST, 2002) and the West African monsoon (SAHA and SAHA, 2001, 2002) as well as rainfall over various climate zones from the arid innermost Sahara to humid tropical climate in the vicinity of the equator.

Touchstones for the reliability of climate models over West Africa are the correct simulation of the complex wind systems and the realistic rainfall prediction in terms of the seasonal cycle and the spatial distribution. PAeth and Hense (2003) have shown that various coarse-grid global climate models are able to portray the basic features of the rainfall patterns. However, rainfall variability is mostly underestimated and strictly depending on the horizontal resolution of orography. Thus, scale interactions, the special role of orography and the predominance of convective rainfall - partly organized in squall lines (REDELSPERGER et al., 2002; SAHA and SAHA, 2002) - require the application of high-resolution numerical models in order to account for the synoptic as well as large-scale processes (DRUYAN et al., 2000). In addition, high-resolution climate models offer a more differentiated view on the regional impacts of increasing GHGs, SST and land use changes and may improve the concepts of seasonal forecast (GARRIC et al., 2002; Mo and Thiaw, 2002; PAeth and Hense, 2003). Moreover, LEBEL et al. (2000) point to the deficiencies of global climate models in supplying useful input data for hydrological modeling studies over the West African subcontinent. Hitherto, only a few regional dynamical downscaling approaches have been undertaken over West Africa.

Among them, VIZY and COOK (2002) have applied the MM5 regional model over a three-month summer period in order to elucidate the role of Gulf of Guinea 
SST on the West African monsoon. The year 1992 has been realized by GALLÉE et al. (2004) with the MAR model. Therefore, DESANKER and JUSTICE (2001) as well as JENKINS et al. (2002) have emphasized the strong need for the application of regional climate models over Africa.

The goal of this study is to improve our knowledge of the mechanisms of interannual rainfall fluctuations at the synoptic scale during a 25 -year hindcast period extending from 1979 to 2003 . Two key factors in precipitation variability - SSTs and large-scale atmospheric circulation as prescribed at the lateral boundaries of the regional climate model sector - are investigated in order to assess their influences on the West African monsoon regime and associated rainfall changes. Compared with former studies, the basic advantage of this work is that a long-term experiment with high resolution and fairly realistic input data is available to shed light onto key factors in African climate. The study is mainly theoretical - except using observational data for the model evaluation - and is based on simulations of the atmospheric regional climate model REMO (JACOB, 2001; JACOB et al., 2001). The analysis consists of two steps: (1) The abilities and deficiencies of REMO are evaluated with respect to various observational data, including the ERA15 (GIBSON et al., 1997), CRU (NEW et al., 2000) and IRD (Institut de Recherche pour le Développement, DiedHiou et al., 2001) datasets. As precipitation is a major limiting factor in food security and human welfare in West Africa, particular emphasis is on the evaluation of simulated rainfall at the regional scale. In addition, the main characteristics of atmospheric circulation are validated in detail, because dynamical variables from the model can be used to adjust biassed model rainfall to the observations. This is the objective of a subsequent analysis. (2) Composites of deficient and abundant simulated monsoon rainfall in the Guinean Coast region are determined and compared with the observations. The related composites in several climate parameters, especially in the context with the oceanic lower boundary and atmospheric lateral boundaries, are described in order to identify the processes and mechanisms leading to wet and dry conditions in the West African monsoon system.

This study is embedded in the framework of the German interdisciplinary IMPETUS project, which represents an integrated approach to the efficient management of scarce water resources in West Africa. Addressing Morocco and Benin, IMPETUS focuses on two West African regions with different climate characteristics, freshwater availability, natural potential and socioeconomic conditions but similar projected developmental problems in the future. An additional goal of our work is to supply high-resolution input data for hydrological and economic models which in turn are supposed to improve agricultural systems and hydrological mea- sures. Therefore, some aspects of the present study concentrate on these two countries. Within IMPETUS, the regional model REMO is part of a hierarchical model chain from global climate models, addressing interannual to interdecadal variability, down to non-hydrostatic meso-scale models, which are even more appropriate to access smallest-scale processes like meso-scale convective systems (MCS) and squall lines (REDELSPERGER et al., 2002). Section 2 gives a brief description of the regional climate model REMO and the observational data used for validation. Section 3 is dedicated to the model evaluation. The aspect of interannual variability and the related mechanisms are addressed in section 4 . In section 5, the results are discussed, especially with respect to the prospects for seasonal forecast and climate change studies.

\section{Description of the model and observational data}

\section{(a) Regional climate model REMO}

The regional model REMO is a hydrostatic regional climate model developed at the Max-Planck Institute for Meteorology on the basis of the former operational weather forecast model Europa-Modell of the German Weather Service (MAJEWSKI, 1991). It has been designed for applications in the synoptic and meso- $\alpha$ scale and was further developed and applied continuously for regional climate modeling (JACOB, 2001).

The dynamical kernel is based on primitive equations with temperature, surface pressure, horizontal wind components, water vapor content and cloud water content as prognostic variables (JACOB et al., 2001). The model equations are transformed on a geographical latitude/longitude grid with a terrain-following vertical coordinate. In the version used within IMPETUS, the horizontal resolution is $0.5^{\circ}$, equivalent to about $55 \mathrm{~km}$ grid spacing at the equator; 20 hybrid vertical levels up to a height of $25 \mathrm{~km}$ are used. The model area covers the West African subcontinent, the Arabic Peninsula and the Mediterranean Sea with adjacent countries.

Physical parameterizations from the global climate model ECHAM4 (RoECKNER et al., 1996), adjusted to the scale of REMO, are implemented. Moist convection is governed by the mass flux scheme by TIEDTKE (1989). A 5-layer soil model describes land surface processes and has a vanishing heat flux at its lowest level in $10 \mathrm{~m}$ depth.

The model is nested in the global ECMWF reanalysis data (ERA15), which is available for the years 1979-1993 (GIBSON et al., 1997), and the corresponding ECMWF analyses for the period 1994 to 2003. The model domain used in this study extends from $30^{\circ} \mathrm{W}$ 
to $60^{\circ} \mathrm{E}$ and from $15^{\circ} \mathrm{S}$ to $45^{\circ} \mathrm{N}$. One long-term experiment has been conducted with realistic lateral and surface boundary conditions from January 1979 to December 2003. Land surface parameters like orography, vegetation, albedo, soil characteristics and roughness length are derived from GTOPO30 (provided by the Land Processes Distributed Active Archive Center (LP DAAC), located at the U.S. Geological Survey's EROS Data Center) and NOAA data (HAGEMANN et al., 1999). Underlying an idealized annual cycle over West Africa, the same daily interpolated surface parameters are prescribed each year. Thus, interannual variability can not arise from changing land surface conditions. In the uncoupled mode, the SST, acting as the lower boundary condition over the oceans, is also taken from the ERA15 data set. For the purpose of this study, REMO is run in the climate mode which means that the model domain is initialized only once by the ERA15 data at the beginning of the integration period. Then, every 6 hours the global input data is prescribed at the lateral margins. The influence of the forcing field exponentially drops down towards the 8th grid point row of the inner model domain. This guarantees that the model can develop its own dynamics within the center of the simulation domain (JACOB et al., 2001). In contrast to sea level pressure (SLP) and horizontal wind components, relaxation of temperature and humidity at the lateral boundary fields is suppressed, if the atmospheric flow directs out of the model domain, in order to avoid artificial rainfall due to barrier effects at the margins. A very large model area has been chosen, including $121 \times 181$ grid boxes, such that artificial boundary effects do only occur in the ultimate 2 to 3 grid box rows along the lateral boundaries but can be excluded in the entire African sector.

Compared with the default version described above, some changes have been made to adapt REMO to the tropical-subtropical West African region. In the Tiedtke convection scheme, the lower threshold of cloud thickness for the generation of rainfall has been set to 1500 $\mathrm{m}$ instead of $750 \mathrm{~m}$. The latter value is generally used for the extratropics. Additionally, the ERA15 SSTs in the tropical Atlantic and Indian Ocean sector appear to be slightly warmer than e.g. the GISST data set. Since tropical precipitation is closely related to SST, this warm bias results in abundant rainfall off the West African coast and reduced rainfall over land. Therefore, the prescribed ERA15 SSTs are systematically corrected towards a slightly colder tropical Atlantic and Indian Ocean. Because tropical atmospheric processes directly respond to intense surface heat gradients, an EOF recombination technique has been applied, using the two leading EOF patterns of the relevant oceanic region for the correction. The EOF recombination reveals moderate SST gradients towards the subtropical oceans and the
Mediterranean Sea which themselves are barely affected by the correction.

\section{(b) Observational data}

The output of the regional model is compared with three sets of observational data. The evaluation of wind, temperature and geopotential refers to the ERA15 data (GIBSON et al., 1997). As the model domain is quite large, extending over 90 parallels and 60 meridians, it is admissible to evaluate the model dynamics directly with the forcing data. The agreement between the ECMWF forcing data and the model output in the inner model region is not self-evident, because no nudging is undertaken within the REMO sector. Observed monthly sums of precipitation, number of rainy days and total cloud cover are provided by the CRU data set in $0.5^{\circ}$ resolution over all land masses except Antarctica and during the 1901-1998 period (NEW et al., 2000). The CRU data set is based on various rain gauge station data all over the globe which are statistically interpolated to a regular grid. POCCARD et al., 2000 have shown that the CRU data is more appropriate to represent the basic features of rainfall variability over West Africa than NCEP and ERA reanalysis products which reveal considerable discrepancies with respect to satellite data (LIM and Ho, 2000). However, satellite data are not used for the model evaluation, since algorithms translating measured radiation to effective rainfall amount are still subject to some uncertainties. Daily rainfall is inferred from the IRD data set which represents a collection of several rain gauge stations over subsaharan West Africa interpolated to a regular $1^{\circ}$ grid (DIEDHIOU et al., 2001). It is noteworthy that the quality of interpolated observational data over West Africa is questionable, especially with respect to sampling errors in rainfall interpolation for instance over orographic terrain or in regions with low station density. Therefore, these data sets do not unambiguously tell the truth.

\section{Model evaluation}

The motivation of downscaling approaches is on the one hand to refine spatial patterns of meteorological variables and on the other hand to assess the impact of larger-scale influences on variability at smaller scales. Dynamical downscaling can be understood as an interpolation of the coarser-grid driving data with additional physical constraints. Statistical downscaling is an alternative approach where empirical relationships between local predictors like geographical latitude, orography, roughness length, distance from coast etc. and the variable to be interpolated are used to refine the horizontal resolution (MEARNS et al., 1999). The method of dynamical downscaling is computationally more expensive than statistical downscaling. However, the success of statistical methods highly depends on the characteristics and quality of meteorological variables. Especially 

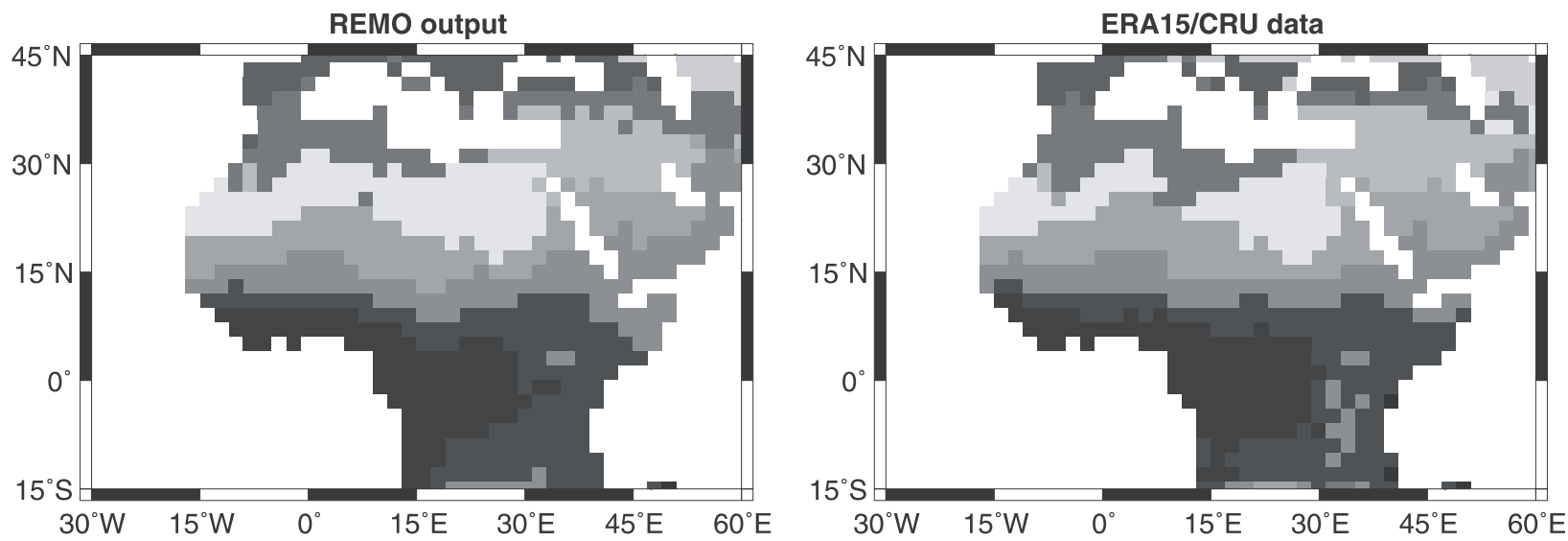

Figure 1: Cluster analysis of near-surface climate parameters: REMO output and combined observational data (ERA15/CRU). For explanation see Table 1.

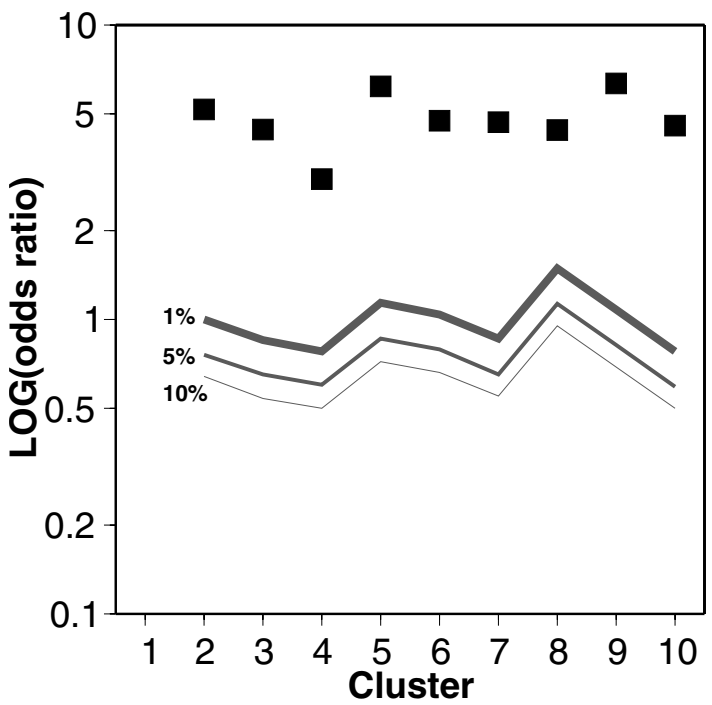

Figure 2: Skill of the cluster analysis as measured by the logarithmic odds ratio of right versus wrong classifications of the REMO clusters given the observed clusters. For explanation see text.

precipitation as a key quantity of the hydrological cycle is subject to large sampling errors due to interpolation. Therefore, regional climate models are particularly required to produce dynamically consistent data sets of meteorological variables like rainfall, cloudiness and humidity which are strongly affected by small-scale processes.

In this section, the simulated model climate is evaluated by comparison with observations. The results are examined with respect to the question, how the model climate compares to the observed climate and if we can understand any systematic differences.

\section{(a) Near-surface climate}

Instead of comparing the parameters of surface climate individually, a cluster analysis has been carried out based on precipitation, total cloud cover, SLP, annual temperature amplitude, near-surface temperature and surface wind components. All data were used as annual values for 1991 , interpolated to a $2^{\circ} \times 2^{\circ}$ grid, because the $0.5^{\circ}$ model grid only allows a resolution of phenomena with a size of at least $2^{\circ}$. The observational data is composed of ERA15 and CRU, depending on the variable. The cluster analysis is based on the centroid method and a subsequent correction algorithm with randomized regroupment (WILKS, 1995). In the present case, a data matrix $X_{i j}$ with $i=1 . . m$ variables and $j=1 . . n$ spatial units is given. As the measure of distance between two clusters $a$ and $b$ the Euclidian distance $d_{a b}$ is used, including a weighting factor in the form of the correlation coefficient $r_{k l}$ between the input fields of variables $k$ and $l$ :

$$
d_{a b}=\sqrt{\sum_{k=1}^{m} \sum_{l=1}^{m}\left(x_{k a}-x_{k b}\right) r_{k l}\left(x_{l a}-x_{l b}\right)}
$$

This measure of distance is able to account for temporal intercorrelation between the input parameters like e.g. between rainfall and cloud cover. A strong correlation enhances the distance between two cluster and, hence, counteracts the classification into one common cluster. This proceeding ensures that the cluster assignment is preferably based on independent data. Once the cluster analysis is accomplished, the centroids of a priorily defined number $c$ of clusters are determined and all original values are again assigned to that cluster, in terms of which the Euclidian measure of distance shows a minimum. Then, the centroids of the new clusters are determined and the method is iterated further on until the new cluster centroids become stationary, implying that the optimal cluster assignment is found. A-priorily, it is set $c=10$. The 10 clusters are derived from the observations and serve also as reference to the REMO output.

In Fig. 1, the 10 clusters are arranged in the order of rainfall amount. In addition, Tab. 1 indicates the departures of the cluster centroids from the overall spatial mean of each input parameter. At first sight, both maps 

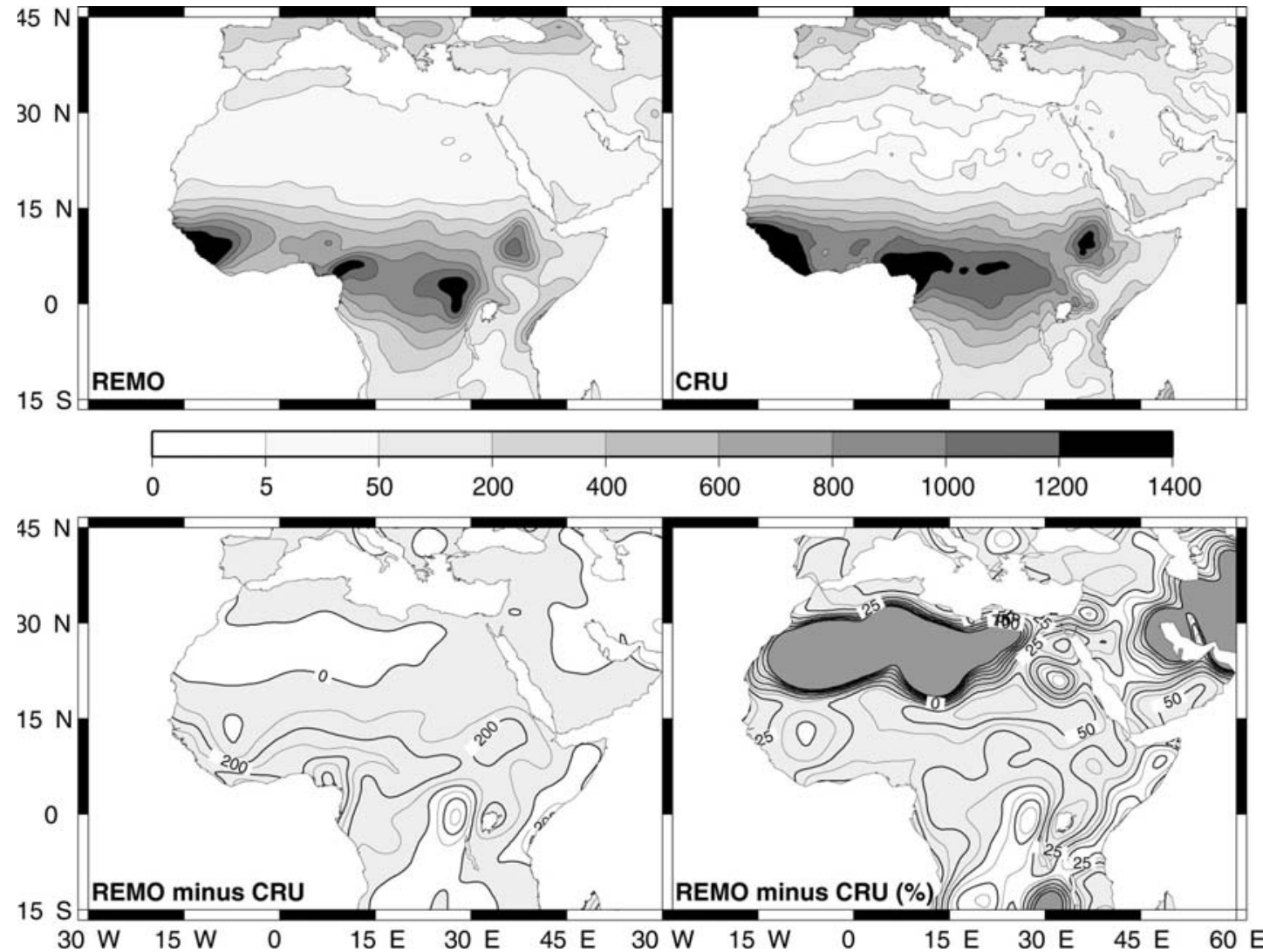

Figure 3: Simulated and observed patterns of total annual rainfall in mm per year averaged over 1979 to 1998 and the systematic differences between both, once in total values, once in \% of the CRU climatological values.

Table 1: Mean standardized departures of the observed clusters in Fig. 1 from the overall spatial mean, graded from positive (cluster

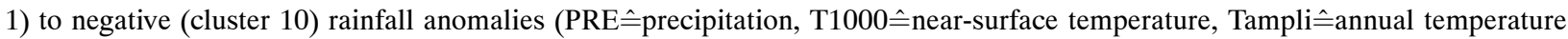

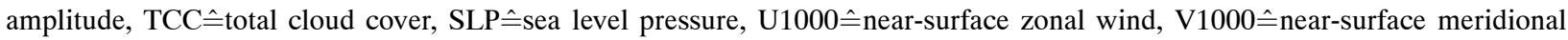
wind).

\begin{tabular}{|c|c|c|c|c|c|c|c|}
\hline stand. anomaly: & PRE & T1000 & Tampli & TCC & SLP & U1000 & V1000 \\
\hline 1 & 3.01 & 0.39 & -1.21 & 1.10 & 1.07 & -1.44 & 2.94 \\
\hline 2 & 1.66 & 0.38 & -1.32 & 1.61 & -0.54 & 1.23 & 0.93 \\
\hline 3 & 0.86 & 0.70 & -0.95 & 0.70 & -0.25 & -0.27 & 0.84 \\
\hline 4 & 0.38 & -2.18 & 1.24 & 0.74 & 1.60 & 0.08 & 0.06 \\
\hline 5 & -0.44 & -1.04 & 0.82 & -0.21 & 1.15 & -0.12 & -0.10 \\
\hline 6 & -0.33 & 0.78 & -0.45 & -0.24 & -0.88 & -0.03 & 0.39 \\
\hline 7 & -0.84 & 0.62 & 0.25 & -0.98 & -0.65 & -0.27 & -0.79 \\
\hline 8 & -0.57 & -0.29 & 0.80 & -0.78 & -0.26 & 1.46 & -0.70 \\
\hline 9 & -0.72 & -2.70 & 2.54 & 0.17 & 1.82 & -1.05 & 0.14 \\
\hline 10 & -0.96 & -0.26 & 0.67 & -1.05 & 0.60 & -1.10 & -1.32 \\
\hline spatial mean: & 560.76 & 22.16 & 23.79 & 0.46 & 1013.42 & -0.42 & -0.57 \\
\hline
\end{tabular}

are very similar to each other and reproduce the wellknown Köppen-Geiger classification of climate zones over Africa and the Mediterranean region: The dark grey boxes represent the wet and hot tropical climates, with positive rainfall and temperature anomalies from the overall spatial mean. The subtropical Mediterranean climate is indicated by the middle-grey areas. Warm arid zones prevail in the Sahara with light grey shading. The grey-scale in the Caucasian region describes cold and arid conditions. Obviously, the regional climate model draws a realistic picture of near-surface climate characteristics even if only one exemplary year is considered. Some minor discrepancies are found in the central Sahara, which seems to be slightly too wet in the model; this problem is related to the Hoggar mountains. In the East African Mountains, a more arid climate is modeled. In the Guinea coast region, a smaller number of points are classified in the most humid cluster. 
It can be shown that there is a statistically significant skill for the correct classification of model grid points into the observed clusters (Fig. 2). The skill is measured by the logarithmic odds ratio $\theta_{c}$ which consists of the hit rate $H$ - the model grid point is classified into the same cluster $c$ as the observations - and the false alarm rate $F$ - model output is classified in another cluster - with $\theta_{c}=\left(\frac{H}{1-H}\right)\left(\frac{1-F}{F}\right)$ and $\log \left(\theta_{c}\right)$ being a Gaussian distributed random variable (STEPHENSON, 2000). $H$ and $F$ can easily be derived from a contingency table, while it is required that all counts $i=1 . .4$ contain at least five grid points. Cluster 1 in Fig. 1 does not meet this criterion. For all other clusters, the classification skill clearly exceeds the $1 \%$ level of the corresponding Nullhypothe$\operatorname{sis} E\left(\log \left(\theta_{c}\right)\right)=0$.

\section{(b) Precipitation}

Precipitation is an important component of the hydrological cycle and the freshwater availability in West Africa. Correct simulation of tropical rainfall requires the correct presentation of atmospheric circulation, orography, surface properties, radiation processes and, especially in the low latitudes, the parameterization of convection and microphysical cloud processes. Simulated rainfall may even be considered as a measure of the "accumulated skill" of the model and the deficiency of rainfall reproduction as the "accumulated model error", provided that the validation data is reliable. Fig. 3 depicts the patterns of simulated and observed total annual precipitation amount averaged over the 1979 to 1998 overlapping period of REMO and CRU (top panels). The systematic differences in total numbers and in $\%$ of the observed climatology are shown in the bottom panels. The CRU observational data are restricted to the land surface. Major differences occur over the area of the river Niger delta and, covering a quite large region, over the Sahara. The western Sahara appears to be slightly too wet (less than $50 \mathrm{~mm}$ per year) and the barrier effect west of the East African mountain ridge is overestimated in the regional model. On the other hand, it is not clear to which extend the CRU data set is unambiguously realistic in mountainous areas. Over extratropical regions particularly over southern Europe and Northwest Africa - where rainfall is associated with large-scale circulation and less sensitive to the annual cycle of vegetation cover, only minor differences between model data and CRU occur. The north-south gradients over West Africa and the rainfall peaks off the western Guinean Coast region and the Cameroon Mountain are quite similar. However, the model reveals very strong gradients along the tropical coasts with much more rainfall over the oceanic grid boxes than over land (not shown) (cf. VIZY and COOK, 2002). This might be due to an overestimated barrier effect of coastal orography in the $55 \mathrm{~km}$ resolution, confronting the onshore monsoon circulation and initializing the moist convection scheme too easily. This implies that moisture advection from the oceanic

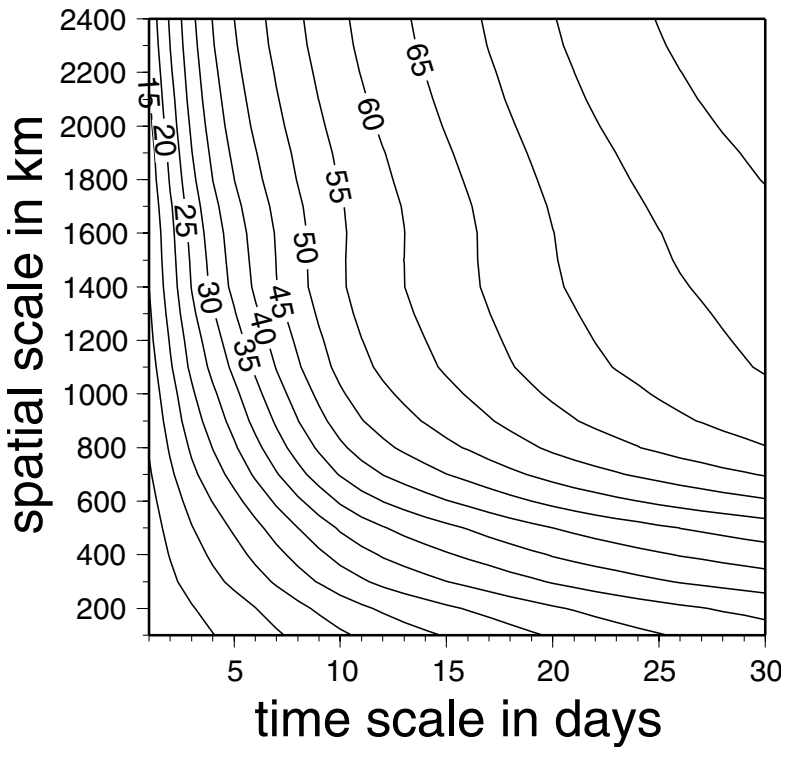

Figure 4: Dependence of the REMO-IRD in-phase relationship of daily precipitation on the selected time and spatial scales. The contour lines denote the explained variance in \% (coefficient of determination).

to the continental atmosphere is reduced, resulting in a systematic underestimation of subsaharan precipitation by up to $40 \%$ of the observed total amount (Fig. 3, bottom panels). For the global model ECHAM4, which suffered from similar deficiencies, it has been shown that a simple dynamical vegetation model, acconting for interactions between vegetation cover, albedo and rainfall, improved the simulation of rainfall over the Sahel (SCHNITZLER et al., 2001). In addition, HoNG and PAN, (2000) pointed to the importance of soil moisture initialization in their regional model over North America. These two caveats were yet not considered in the REMO model. As the model error is of systematic nature, an alternative to the implementation of dynamic vegetation and the assimilation of soil moisture data is a statistical postprocessing of the REMO rainfall using model output statistics (PAETH and HENSE, 2003). This method consists of a cross-validated multiple regression model, which adjusts the deficient simulated precipitation to the observed characteristics using exclusively the information from the simulated dynamical variables, which do not suffer from inaccuracies in the presentation of rainfall and cloud processes (see below).

It is of major relevance to climatological and hydrological applications to know on which temporal and spatial scales model precipitation coincides with the observations. This dependence is displayed in Fig. 4. The time scales vary from 1 to 30 days, the spatial scales from 100 to $2400 \mathrm{~km}$. The contour lines denote the coefficient of determination between modeled and IRD rainfall as mean over all available grid boxes or regional means within the IRD region $\left(20^{\circ} \mathrm{W}-26^{\circ} \mathrm{E} ; 0^{\circ}-23^{\circ} \mathrm{N}\right)$. As expected, the correlation between model output and 


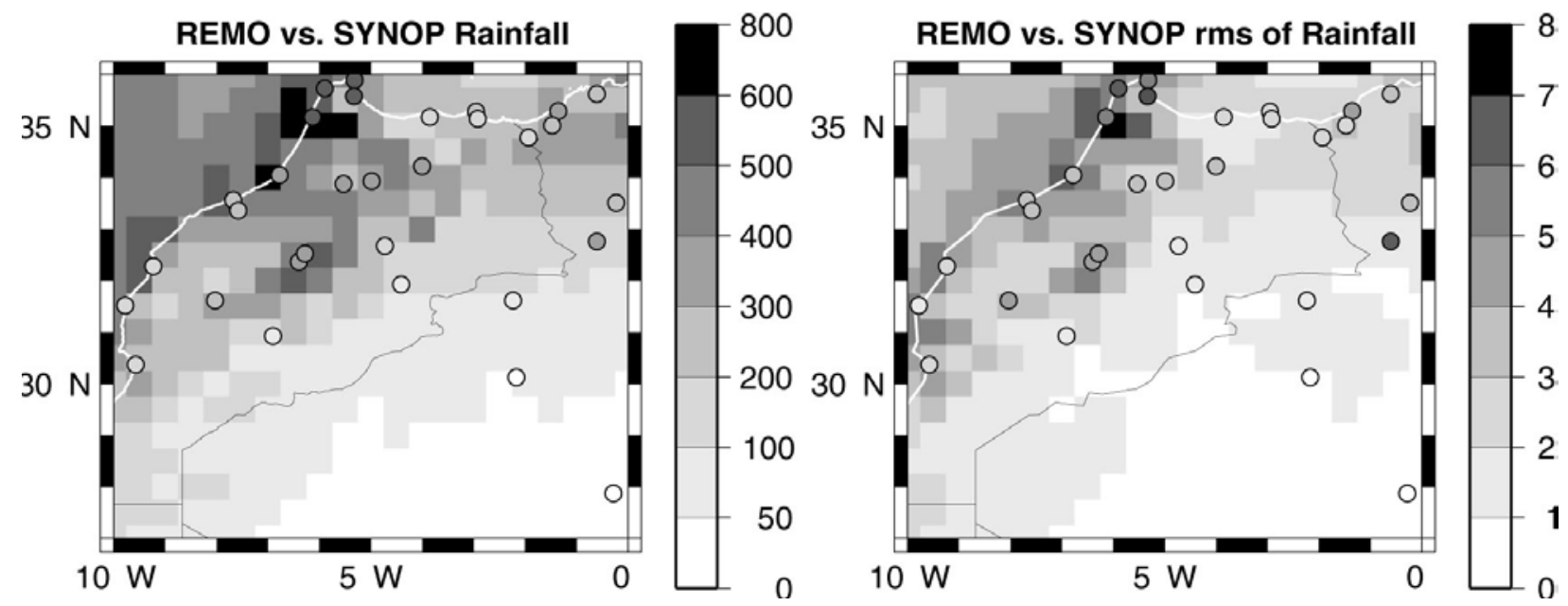

Figure 5: REMO rainfall (boxes) as a spatial "gap filler" over Morocco with low station density (circles), total annual rainfall in mm and daily standard deviation in $\mathrm{mm}$.

REMO EOF 1-6 (93.9\%)
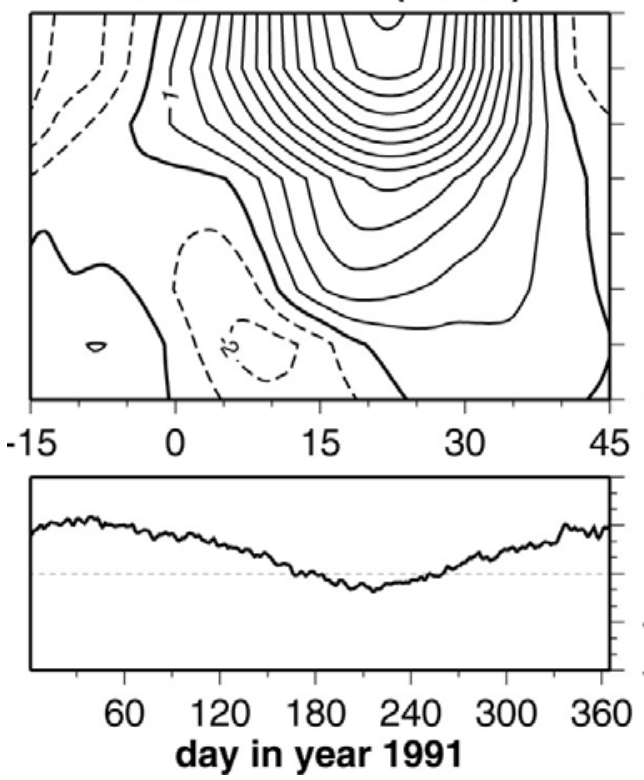

ERA15 EOF 1-6 (94.3\%)
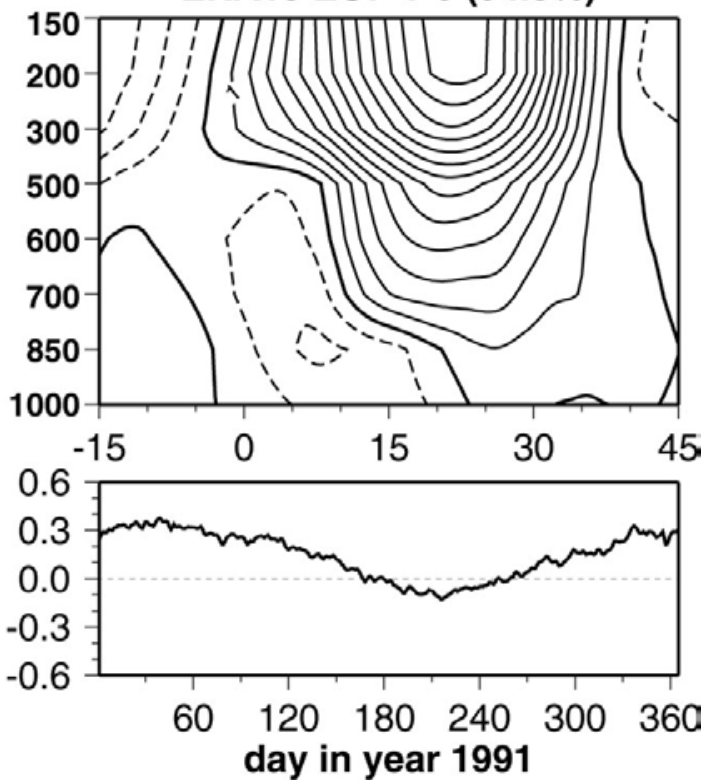

Figure 6: (Top) Cross-section of the Latitude-hight linear combination of the leading six EOFs of daily zonal wind averaged from $30^{\circ} \mathrm{W}$ to $60^{\circ} \mathrm{E}$ : REMO and ERA15. The contour interval is 1 unit of the normalized EOF amplitudes. Negative (positive) values denote eastward (westward anomalies). The numbers in brackets indicate the total explained variance of the leading 6 EOFs in \%. (Bottom) Principal component time series in $\mathrm{m} \mathrm{s}^{-1}$ derived from the projection of the data onto the linear combination of the leading six EOFs.

IRD is rising with increasing aggregation in space and time. In the upper right corner the correlation coefficient amounts to 0.92 , indicating that the simulated annual cycle in the whole subsaharan regional-mean is almost exactly in phase with the observed one. Note that this does not imply that the total precipitation amount as simulated by REMO matches the observed values at a monthly scale. Fig. 3 clearly reveals that this is not the case in the entire region, since subsahelian rainfall is systematically underestimated by the model. In the opposite corner it is clearly revealed that the regional model is not able to reproduce rainfall at the same day and in the same grid box as observed. Given the large model domain, the $55 \mathrm{~km}$ grid size and the lack of surface feedbacks, this result is not surprising. If a specific application is dedicated to single observed precipitation events, it should only refer to time scales larger than 10 days or to regional-mean data. However, the lack of in-phase relationships between simulated and observed variables does not imply that REMO output at daily time scales and individual grid points cannot be considered for further analyses. For many climatological issues at these spatio-temporal scales, it is more important that the model simulates the correct long-term mean and variability correctly. 


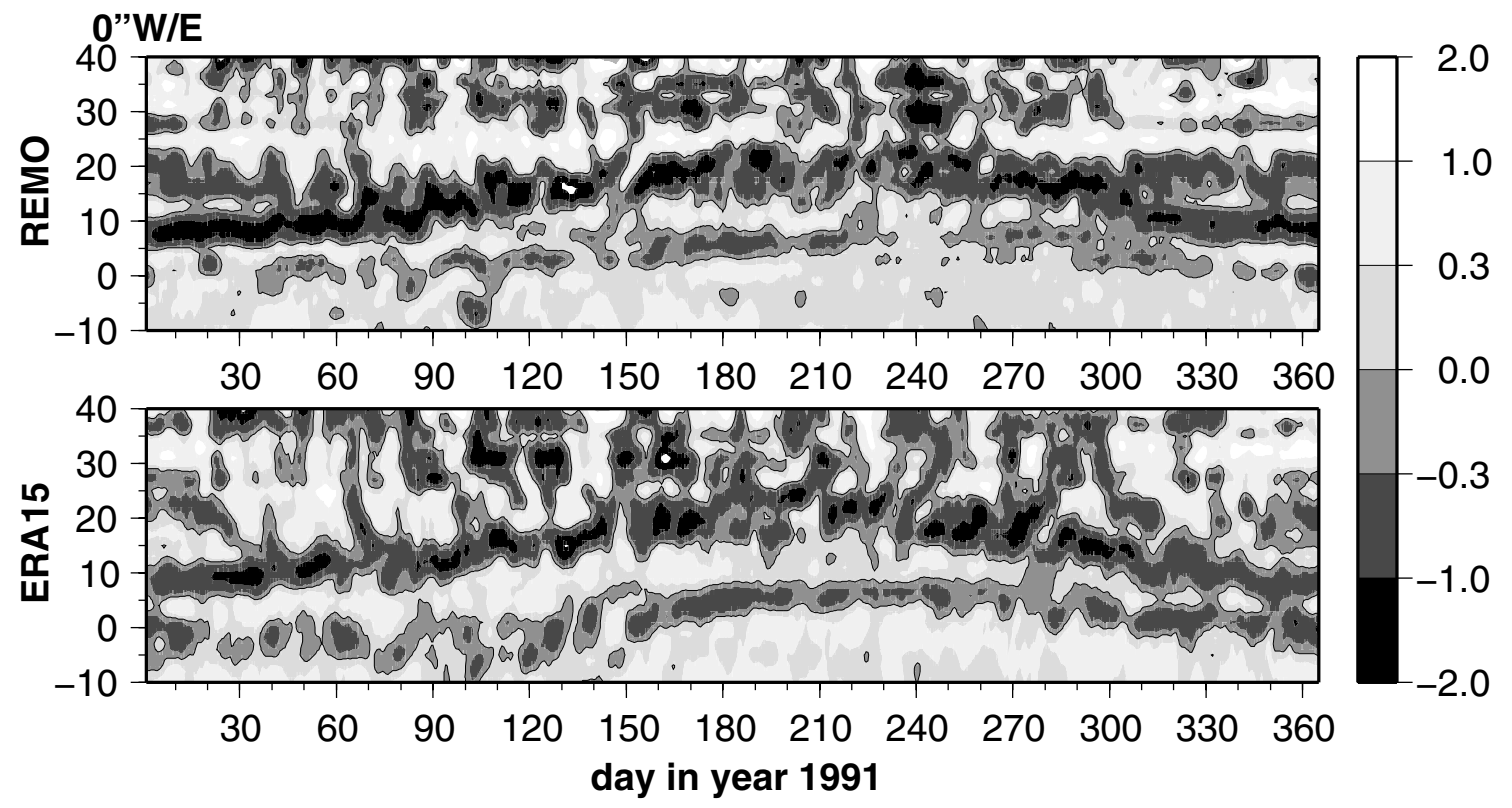

Figure 7: Hovmöller diagram of surface wind divergence (ITCZ) at $0^{\circ} \mathrm{W} / \mathrm{E}, 5$-day filtered data in $10^{-5} \mathrm{~s}^{-1}$ : REMO and ERA15. Negative values denote wind convergence.

Especially in regions with inadequate station data coverage, such model simulations can fill the spatial and temporal gaps. Northwest Africa as one focus area of the IMPETUS project this study is embedded in (see section 1) represents such a region, where a small number of station observations is confronted with enhanced spatial heterogeneity in orographic terrain (Fig. 5). It is obvious that the model is in good agreement with the pointwise information provided by the 32 rain gauge stations. This holds for the total amount as well as for the day-today variability during the reference year 1991. Thus, the regional model can supply high-resolution rainfall data with reasonable patterns of total annual amount and dayto-day variability over Morocco, where observational data barely exist and statistical interpolation fails because of the intense orographic variance.

\section{(c) Circulation}

Tropospheric circulation over West Africa is characterized by several mainly zonal wind features in different atmospheric levels and with a distinct annual cycle (SAHA and SAHA, 2001). Fig. 6 depicts the linear combination of the leading 6 EOFs of the zonal-mean $\mathrm{u}$-wind component based on daily data of the regional model and ERA15 in 1991. The associated time series are determined by projecting the daily data onto the linear combination of EOFs 1-6. Note that this picture does not reflect the jet wind maxima themselves but the zonal wind variability during the annual cycle. The leading 6 EOFs account for around $94 \%$ of total u-wind variance. During the summer months, near-surface westerly anomalies, indicative of the West African summer monsoon circulation, occur between $20^{\circ} \mathrm{N}$ and the equator. In the upper tropical troposphere, easterly wind anomalies propagate northward during springtime and vice versa in autumn. This process describes the meridional displacement of the TEJ within the annual cycle (HASTENRATH, 2000). Towards the extratropics, a similar shift occurs for the subtropical westerly jet but of opposite sign. The AEJ in $600 \mathrm{hPa}$ is not readily seen in this illustration because its variability during the seasonal cycle is not comparable with the other zonal wind phenomena over West Africa. The position of the AEJ at a daily time scale is highly variable in space and usually meandering in the form of the AEWs (GRIST and NICHOLSON, 2001), which can not be represented in this zonal-mean picture. It is slightly indicated by the downward propagation of stronger wind anomalies in Northern Hemisphere summer between $15^{\circ}$ and $20^{\circ} \mathrm{N}$. Comparison of EOF patterns and time series reveals that the simulated zonal-mean circulation is very close to the observations in terms of the distribution, amplitude and annual cycle. Even the high-frequency fluctuations of the time series appear to be very similar, indicating that wind variables may have a hindcast potential already on shorter time scales than rainfall (cf. Fig. 4).

In the following, some features of atmospheric circulation over Africa will be elucidated in more detail. A key factor of West African monsoon rainfall is the position of the intnertropical convergence zone (ITCZ) and its annual cycle (HASTENRATH, 2000). The Hovmöller diagrams in Fig. 7 evaluate the dynamics of the simulated ITCZ with respect to the ERA15 data based on pentadal means of surface wind divergence in 1991 at $0^{\circ} \mathrm{W} / \mathrm{E}$. From April onward, the ITCZ is shifting northward to about $20^{\circ} \mathrm{N}$. During summertime, a second weaker ITCZ occurs at $6^{\circ} \mathrm{N}$ near the Guinean Coast, as already mentioned by HASTENRATH (2000). In autumn, the ITCZ returns to its original position and the second 

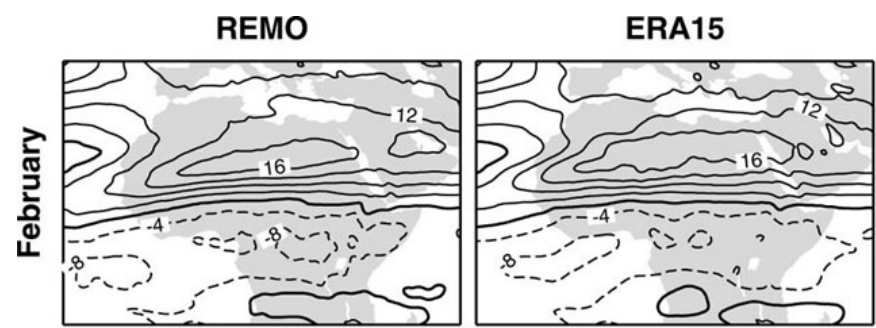

REMO minus ERA15
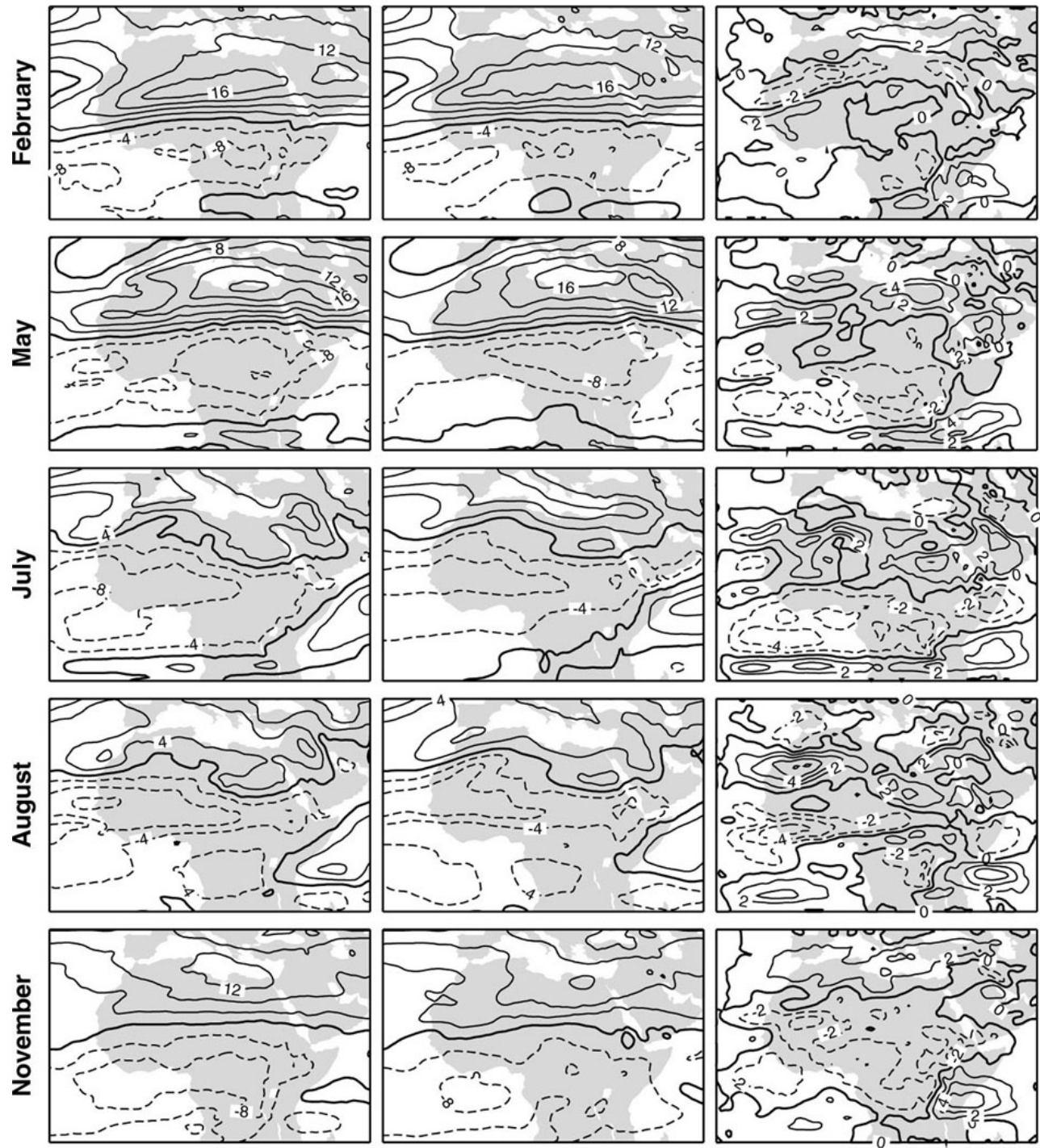

Figure 8: Monthly-mean zonal wind in $600 \mathrm{hPa}$ : REMO, ERA15 and systematic differences in 1991. Negative/positive values denote easterlies/westerlies. The contour interval is $4 \mathrm{~m} \mathrm{~s}^{-1}$ (left and middle column) and $2 \mathrm{~m} \mathrm{~s}^{-1}$ (right column), respectively.

branch disappears. The seasonal variation of the latitudinal position and the split-up of the ITCZ in summer appear also in the regional model.

The position of wind maxima in $600 \mathrm{hPa}$ is an indicator of the mid-tropospheric AEJ, which also exhibits a distinct annual cycle. The simulated and observed monthly-mean u-wind in $600 \mathrm{hPa}$ is displayed in Fig. 8 for various months throughout the year. In boreal winter, westerlies are prevailing over much of West Africa. During springtime, the AEJ intensifies and shifts northward up to $15^{\circ} \mathrm{N}$ in summer. The wind maximum is located over the western part of the subcontinent. In November the westerlies are regaining predominance. The difference patterns to the right of Fig. 8 indicate that the amplitudes of westerly and easterly wind peaks are larger in the regional model than in ERA15. Nevertheless, the reproduction of the AEJ wind maximum throughout the seasonal cycle suggests that the model is able to describe West African circulation correctly, since the generation of the AEJ requires the correct simulation of radiative and adiabatic processes as well as realistic surface conditions (COOK, 1999; GRIST and NICHOLSON, 2001).

In its northernmost position during summer, the AEJ is usually meandering in the form of wave-like disturbances (AEWs), which are primarily induced by orography (THORNCROFT and Hodges, 2001; SAHA and SAHA, 2002) or near-surface heating areas in continental Africa (Nick HALL, personal communication). AEWs can be illustrated as Hovmöller diagram of the meridional wind in $600 \mathrm{hPa}$ at $15^{\circ} \mathrm{N}$ (GRIST, 2002). Fig. 9 shows that the characteristics of the AEWs in the regional model and the reanalysis data resemble each other in several respects: From May through October meridional wind anomalies are originating at $30^{\circ} \mathrm{E}$ and propagating westward to the subtropical Atlantic. The typical time scale is around 6 days which is in agreement with the NCEP reanalysis in GRIST (2002). The lower panel in Fig. 9 shows that the observed and sim- 


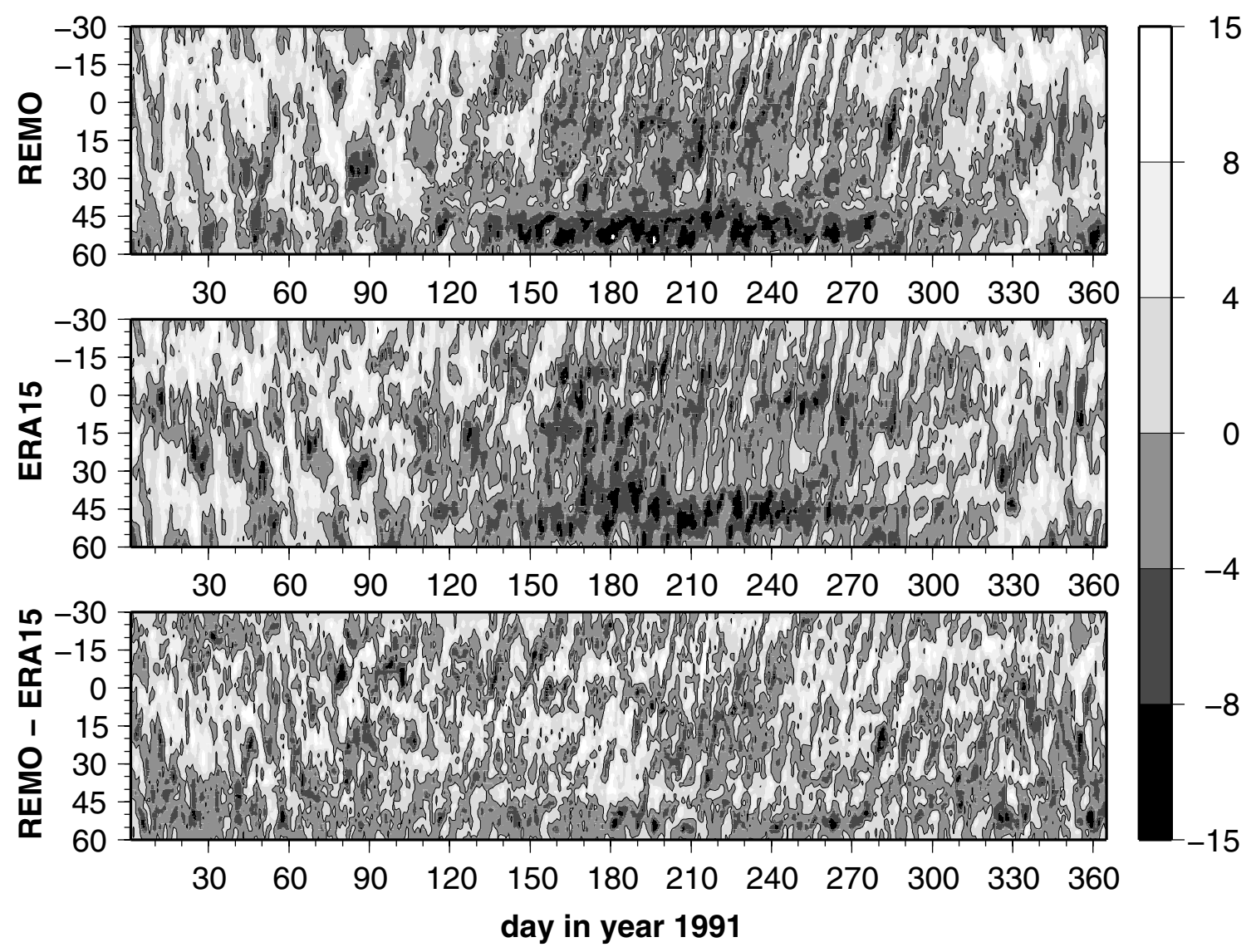

Figure 9: Hovmöller diagram of meridonal wind in $600 \mathrm{hPa}$ at $15^{\circ} \mathrm{N}$, 6-hour data in $\mathrm{m} \mathrm{s}^{-1}$ : REMO, ERA15 and systematic differences. Negative/positive values denote northerlies/southerlies.

ulated AEWs are not in-phase. This indicates that the regional model does not exactly reproduce the patterns of the driving data, but develops its own smaller-scale variability.

Another circulation phenomenon linked to West African rainfall is the interaction between the upper tropospheric TEJ (HASTENRATH, 2000) and the subtropical westerly jet (STJ). The Hovmöller diagrams of zonal wind in $200 \mathrm{hPa}$ at $0^{\circ} \mathrm{W} / \mathrm{E}$ indicates that from winter to summer the TEJ/STJ-pattern shifts northward (not shown). Accordingly, the STJ at $20^{\circ} \mathrm{N}$ weakens in summer. At the end of the year the TEJ completely breaks down. Again, the model output and the reanalysis data are in good agreement (not shown). The TEJ will play an important role in section 4, when the key factors in interannual variability are discussed.

In summary, these results clearly indicate that the regional model can simulate the atmospheric circulation over West Africa in a reasonable way. For subsequent applications e.g. in hydrology, the close relationships between ITCZ, AEJ, AEWs, TEJ and African precipitation allow a postprocessing of the REMO output with respect to the deficient subsaharan precipitation, which may even improve the tools for seasonal forecasting (PAETH and HENSE, 2003).

The validation results, mostly described for the reference year 1991, do not differ notably between the overlapping years 1979 to 1998 . However, the question arises whether the regional model is also suitable to simulate the observed interannual variations of rainfall and climate in the West African monsoon area. No interannual changes in land cover are taken into account. Thus, interannual variability can only be induced by the prescribed oceanic and atmospheric boundary conditions at the ocean surface and lateral margins, respectively. In the following section, composites of wet and dry years are compared with each other in order to detect the relative impacts of oceanic heating and global circulation on rainfall changes in the Guinean Coast region.

\section{Composites of wet and dry years}

Subsaharan precipitation exhibits large interannual variations with great relevance to food production systems (BENSON and ClAy, 1998; NiCHOLSON et al., 2000). Understanding the dynamical processes and impact factors may imply the possibility of seasonal forecast over West Africa (PAeth and Hense, 2003) and even the prediction of future climate changes (Hulme et al., 2001; PAETH and Hense, 2004). For this purpose, composites of the five driest and wettest years during the 1979-1998 overlapping period are determined (Fig. 10). The focus is on the central Guinean Coast region, including Benin, Togo, Ghana and Côte d'Ivoire, since 


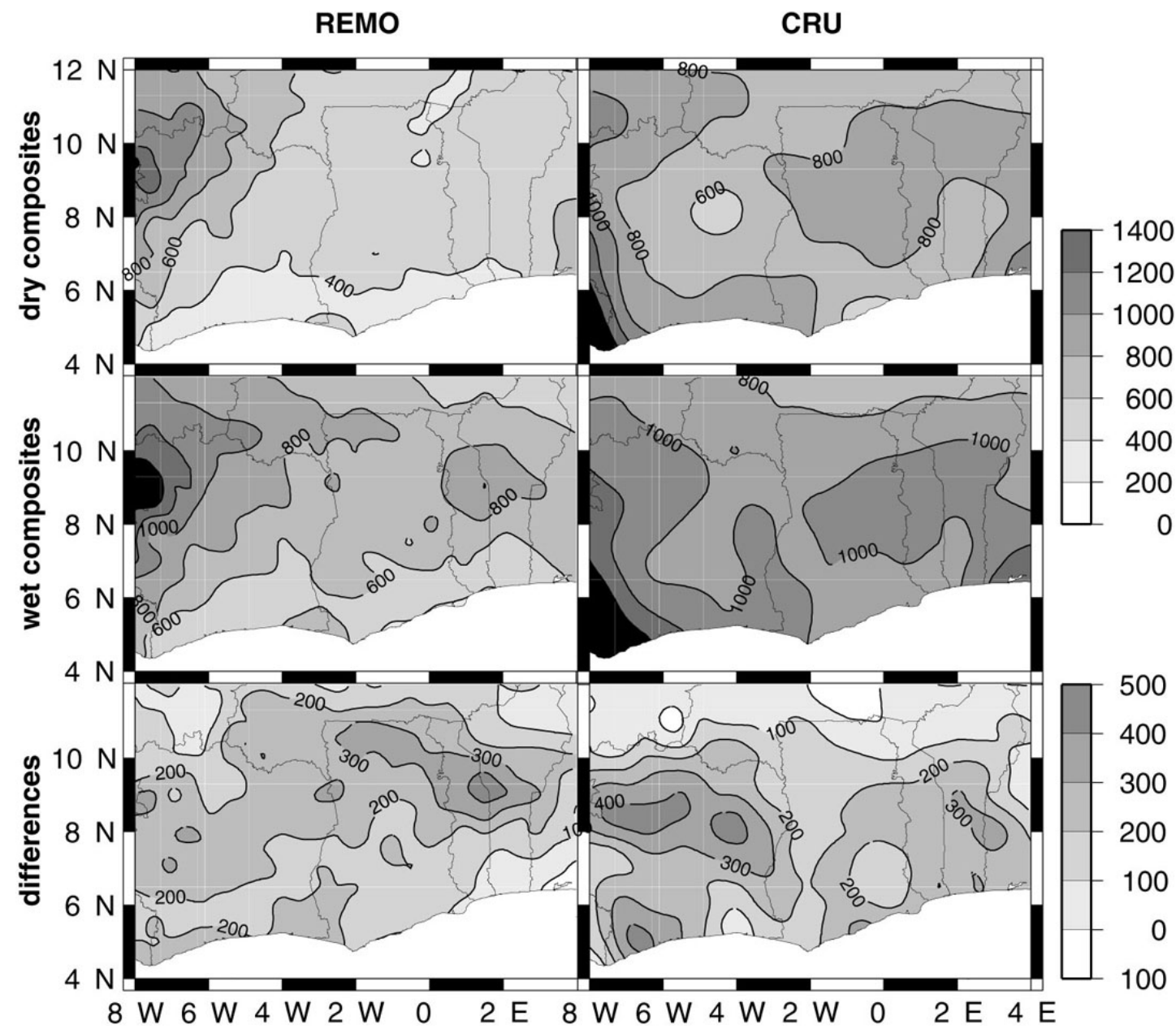

Figure 10: Composites of the 5 dryest and wettest years within the 1979-1998 period as derived from REMO May-October rainfall in mm as well as the corresponding differences. The dryest years comprise 1981, 1983, 1990, 1992 and 1998. The wettest years are given by 1979, 1984, 1988, 1989, and 1991.

this sector represents a key region of the West African monsoon system. The dry years as derived from simulated rainfall have been 1981, 1983, 1990, 1992 and 1998, whereas abundant monsoon precipitation occurred in 1979, 1984, 1988, 1989, and 1991. The CRU data set reveals almost the same composite years, except replacing the dry year 1981 by 1982 and the wet year 1984 by 1985 . The time series in PARKER and AlEXANDER (2002) basically confirm this selection, although they refer to the Sahel region. Fig. 10 displays the composites of deficient and abundant monsoon rainfall in tropical West Africa, once for REMO, once for CRU using the same composite years. Comparing the REMO and CRU composites with each other shows that the model underestimates observed precipitation under dry and wet conditions to the same extent. The amplitude of interannual rainfall variability achieved from model data seems to be in good agreement, at least in terms of the 5-year composites of extreme monsoon rainfall anomalies. In detail, there are some differences between model and CRU data: For instance, the largest amplitude of rainfall anomalies is shifted eastward in the model. In addition, the CRU data also reveal some areas in the southern
Sahel where the sign is reversed. The model simulation neglects some driving forces of African climate variability like land cover changes. Nevertheless, the agreement between the bottom panels in Fig. 10 leads to the conclusion that interannual monsoon variability is at least partly connected to changes in the lower and lateral boundary conditions as prescribed by the oceanic and atmospheric forcing data.

Scaling down to Benin, Fig. 11 gives insight into the daily characteristics of simulated and observed rainfall during a selection of normal, abundant and deficient monsoon seasons, according to the composite years mentioned above. Although Fig. 4 has shown that the simulated daily precipitation events are not in phase with the observations, the model can still simulate the characteristics of daily precipitation, like for instance the mean intensity, in a correct way. Note that this countrywide aggregated consideration of rainfall does not account for the small-scale spatial variability of precipitation simulated at the grid point basis. On the other hand, the $0.5^{\circ}$ resolution of the model can not capture some of the long-lived meso-scale convective systems, which contribute to total rainfall amount in subsaharan Africa 

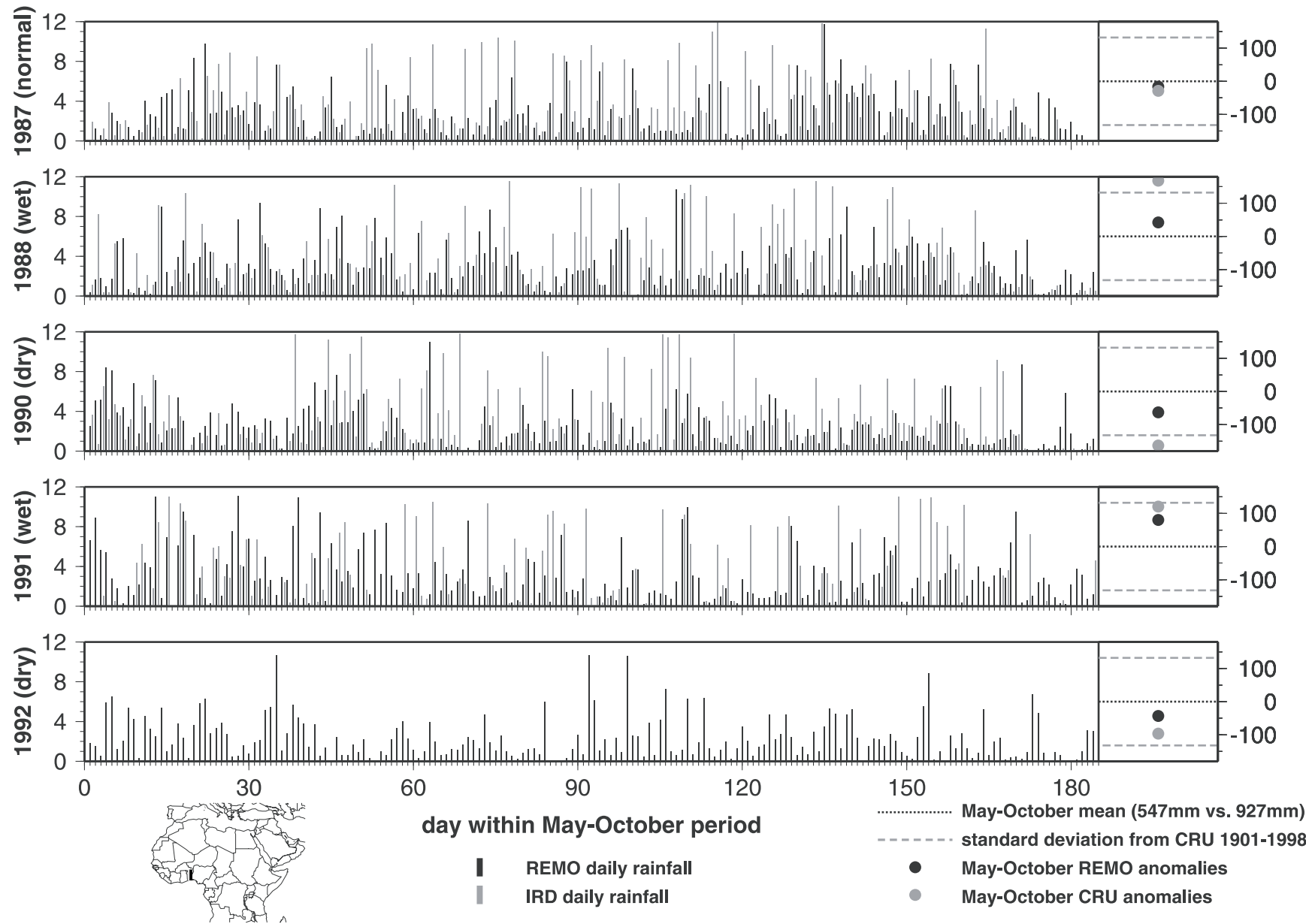

Figure 11: Daily rainfall in $\mathrm{mm}$ in Benin during the rainy season May-October in 5 years with different monsoon abundance: REMO, IRD and statistics from CRU.

(REDELSPERGER et al., 2002). First, the model failure in simulating rainfall events exactly at the same day as observed is obvious. The model tends to generate more events than suggested by the IRD data but of lower intensity, which seems to be a general problem of atmospheric models with convection parameterizations based on mass flux schemes (cf. ZoLiNA et al., 2004). In both data sets, relatively dry years come along with less frequent events but their intensity is barely affected. To the right, the simulated and observed departures from the 5year mean over Benin are compared with respect to the long-term standard deviation (STD) of the CRU data. Indeed, model and observations agree in classifying 1988 and 1991 (1990 and 1992) in wet (dry) and 1987 in intermediate summer monsoon seasons. However, the regional model clearly underestimates the individual amplitudes of the year-to-year changes. This is possibly due to the lack of feedbacks with the land surface, which are supposed to enhance the intensity of interannual climate variability (ZENG et al., 1999; NICHOLSON, 2001; Douville, 2002). However, the fact that REMO is able to reproduce the observed year-to-year changes of precipitation amount in Benin implies that interannual rainfall variability in this region primarily arises from the lateral and/or the lower boundary conditions, which are prescribed every six hours. The initial conditions of the model integration should play a minor role, because the effect of the initial field is damped out after a couple of model days. Sensitivity studies have shown that the impact of SST changes largely exceeds the influence of the initial conditions (PAETH and STUCK, 2004). Concerning the lower boundary conditions, only the SST field may impose interannual variability because the land surface parameters are prescribed without year-to-year changes.

The following figures all refer to the May through October period, once for the dry composites, once for the wet composites and once for the differences between both, as defined in Fig. 10. The composites of zonal and meridional wind at the lateral boundaries are shown in Fig. 12. One hypothesis for instance is that anomalously strong easterly winds, pescribed at the eastern lateral boundary, may strengthen the middle and upper tropospheric circulation phenomena within the model domain like the TEJ, AEJ and AEWs, which in turn affect the amount and distribution of subsaharan rainfall (GRIST and Nicholson, 2001; Hastenrath, 2000). Adequately, enhanced westerly and southerly winds over the tropical Atlantic may be indicative of enhanced advection of humid maritime air masses into West Africa. 

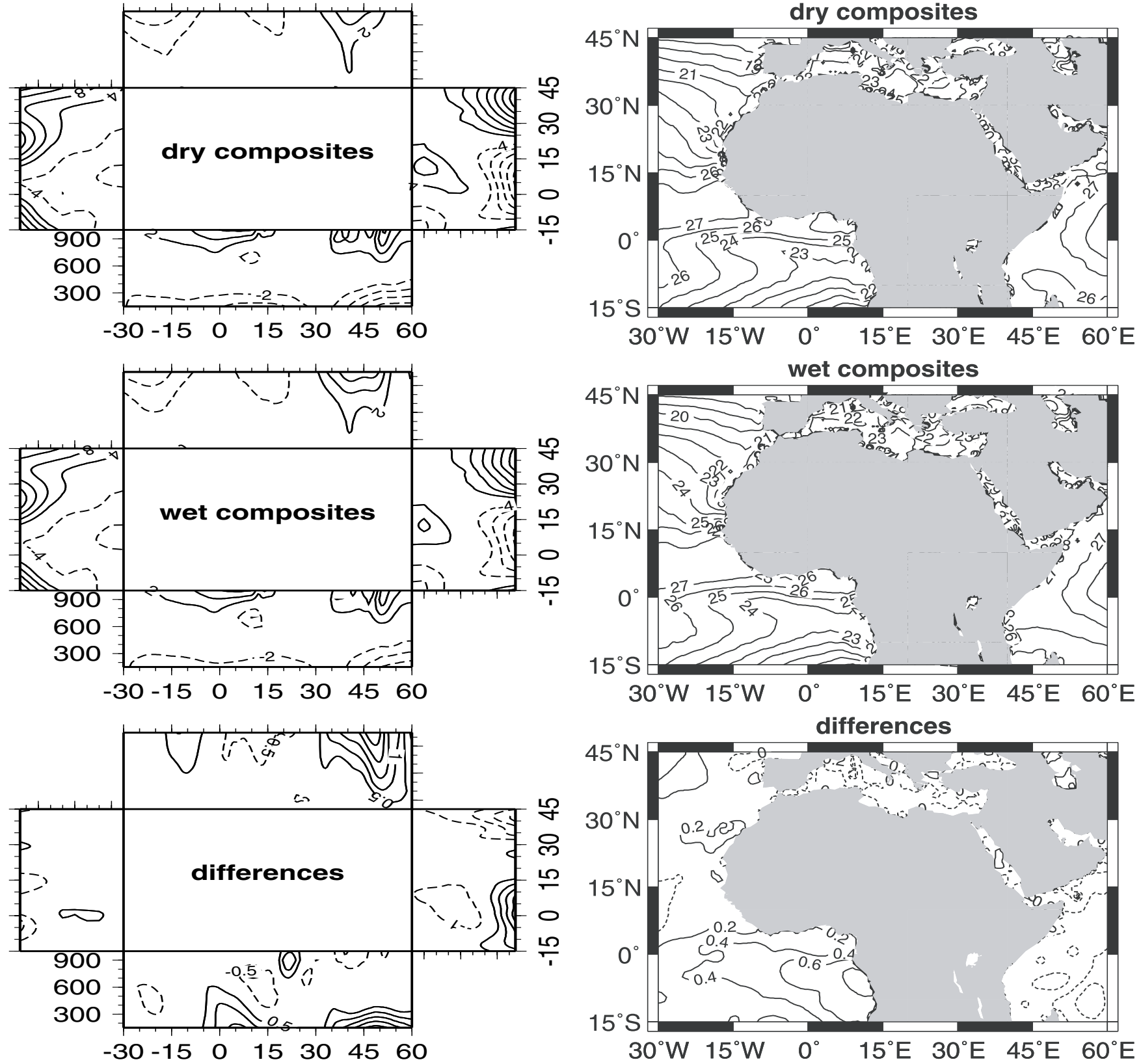

Figure 12: Wind forcing and respective differences at the lateral boundaries associated with the dry and wet composites as defined in the caption to Fig. 10. The blank area in the middle represents the model domain over Africa, the zonal wind forcing is given by the left (western cross section) and right (eastern cross section) panels, while the upper and lower panels denote the meridional wind component at the northern and southern boundaries, respectively. The contour interval is $4 \mathrm{~m} \mathrm{~s}^{-1}$ (zonal, composites), $2 \mathrm{~m} \mathrm{~s}^{-1}$ (meridional, composites), $1 \mathrm{~m} \mathrm{~s}^{-1}$ (zonal, anomalies) and $0.5 \mathrm{~m} \mathrm{~s}^{-1}$ (meridional, anomalies), respectively. Dashed lines indicate easterly and northerly wind (anomalies).

The panels in Fig. 12 draw a clear picture: Although the mean states of dry and wet composites are characterized by rather similar wind characteristics at the lateral boundaries, the wet years show a considerable decrease in the strength of both the TEJ and the STJ at

Figure 13: SST patterns at the lower domain boundary associated with the dry and wet composites as defined in the caption to Fig. 10 and the respective differences. The contour interval is $1^{\circ} \mathrm{C}$ and $0.2^{\circ} \mathrm{C}$, respectively. Dashed lines indicate negative anomalies.

$60^{\circ} \mathrm{E}$ (bottom panel). No changes are found in the nearsurface westerlies (southerlies) at the western (southern) boundaries over the tropical Atlantic. The outflow of (moist) air in the upper troposphere at the southeasterly boundaries of the model area weakens slightly. In addition, the outflow of upper tropospheric (dry) air over the Caucasian region is enhanced in wet years. These two dominant differences indicate a change in the mean direction of the large jet streams at the eastern boundaries of the model area: the southerly branch of the TEJ over the Indian Sea - directed from the Horn of Africa southwards - is reduced in wet years, whereas the STJ 


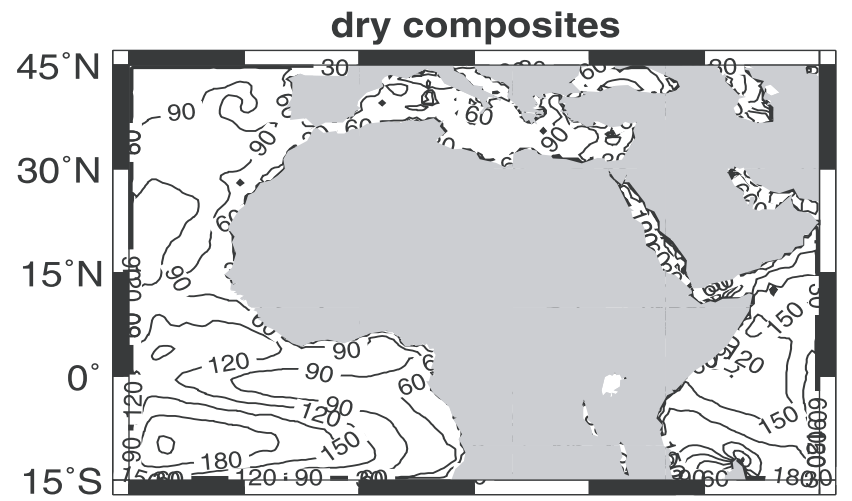

$30^{\circ} \mathrm{W} \quad 15^{\circ} \mathrm{W} \quad 0^{\circ} \quad 15^{\circ} \mathrm{E} \quad 30^{\circ} \mathrm{E} \quad 45^{\circ} \mathrm{E} \quad 60^{\circ} \mathrm{E}$ wet composites
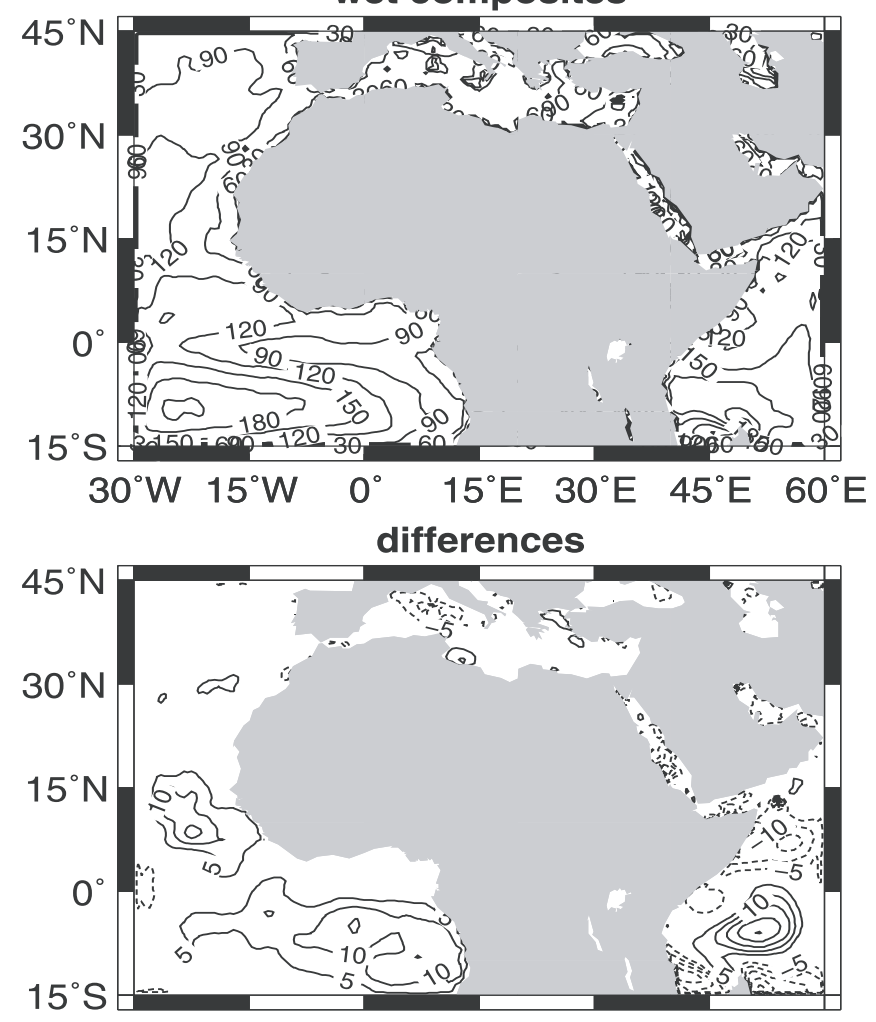

$30^{\circ} \mathrm{W} \quad 15^{\circ} \mathrm{W} \quad 0^{\circ} \quad 15^{\circ} \mathrm{E} \quad 30^{\circ} \mathrm{E} \quad 45^{\circ} \mathrm{E} \quad 60^{\circ} \mathrm{E}$

Figure 14: Same as Fig. 13 but for latent heat flux in $\mathrm{W} \mathrm{m}^{-2}$ The contour interval is $30 \mathrm{~W} \mathrm{~m}^{-2}$ and $5 \mathrm{~W} \mathrm{~m}^{-2}$, respectively. Positive values denote upward fluxes from the surface into the atmosphere (anomalies).

shows a stronger northward component. In addition, the westerly outflow in the lower troposphere over the Indian Ocean is weaker. Since these large scale dynamical changes are connected with changes in moisture advection, they lead to more humid conditions over northern Africa. These findings suggest that West African monsoon rainfall variability is at least partly tied to largescale variations of the upper tropospheric jets.

In the following, the regional SST field is examined. It is one of the key factors in West African rainfall (CHANG et al., 2000; NiCHOLSON, 2001; ViZY and CoOK, 2001). Usually, abundant rainfall in the West African monsoon region is related to warm tropical At-

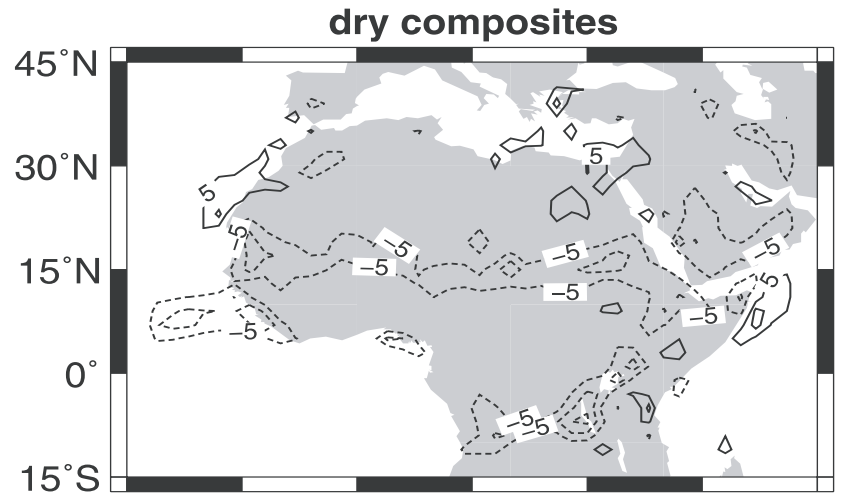

$30^{\circ} \mathrm{W} \quad 15^{\circ} \mathrm{W} \quad 0^{\circ} \quad 15^{\circ} \mathrm{E} \quad 30^{\circ} \mathrm{E} \quad 45^{\circ} \mathrm{E} \quad 60^{\circ} \mathrm{E}$ wet composites
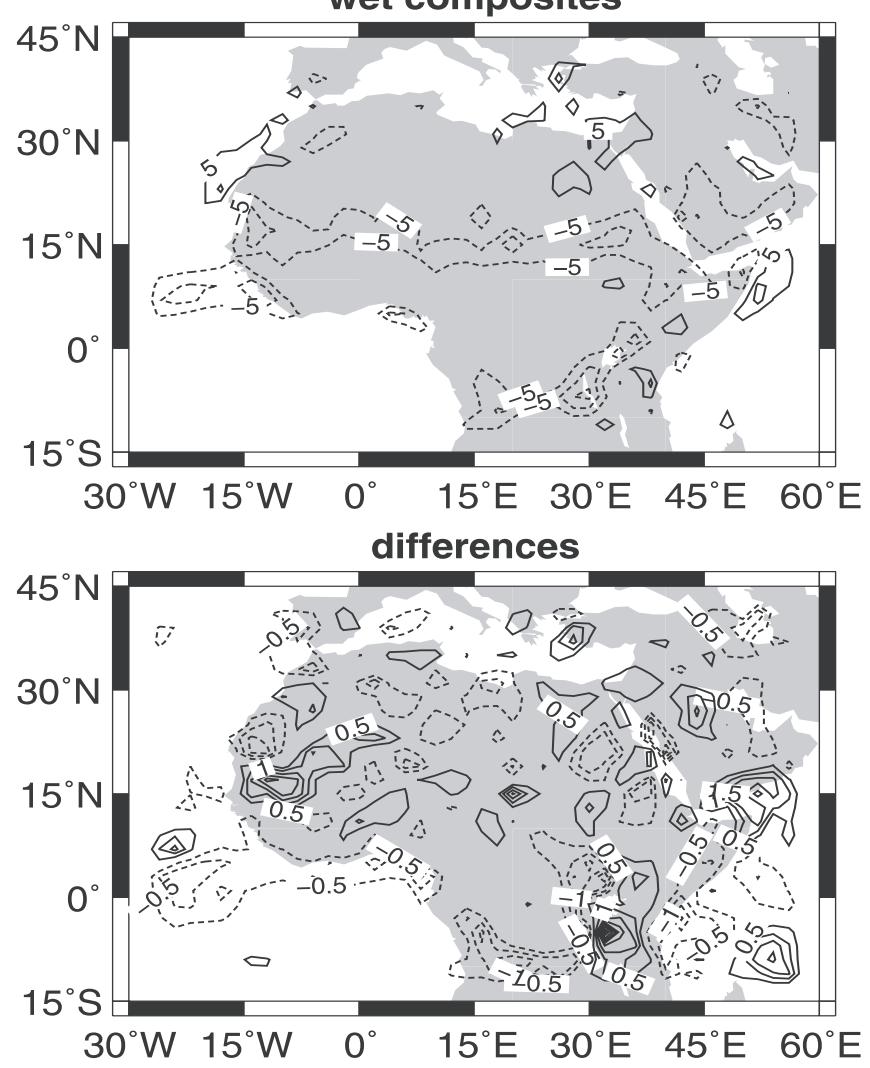

Figure 15: Same as Fig. 13 but for surface wind divergence in $10^{-6} \mathrm{~s}^{-1}$. The contour interval is $5 \cdot 10^{-6} \mathrm{~s}^{-1}$ and $0.5 \cdot 10^{-6} \mathrm{~s}^{-1}$, respectively. Negative values denote wind convergence (anomalies).

lantic SST anomalies. Fig. 13 confirms that relatively dry summer monsoon seasons come along with a colder than normal tropical Atlantic. Abundant rainfall is associated with oceanic heating in the tropical Atlantic by up to $0.8^{\circ} \mathrm{C}$. The shape of the anomaly pattern in the bottom panel is reminiscent of the cold tongue of the Benguela current (SAHA and SAHA, 2001). At the same time, colder than normal SSTs prevail in the Indian Ocean (BADER and LATIF, 2003), but the amplitude is less pronounced. The often cited interhemispheric Atlantic SST dipole (ENFIELD et al., 1999) is barely realized, although a small area of negative SST anomalies is indicated in the westernmost part of the Northern 
Hemisphere tropical Atlantic. VIZY and CoOK (2001) have suggested a linear physical mechanism, transferring changes in the tropical Atlantic SSTs to anomalies of monsoon precipitation. This mechanism involves a linear Kelvin and Rossby wave response to oceanic heating and affects latent heat fluxes and wind divergence over the entire sector. VIZY and COOK (2002) have also found that the MM5 regional climate model principally obeys this linear mechanism, but they only considered two short-term sensitivity experiments. In our 25-year simulation, which is close to the observed climate variations since 1979, warmer SSTs are generally accompanied by enhanced latent heat fluxes from the ocean surface into the atmosphere (Fig. 14). In the tropical Atlantic, the difference pattern corresponds to the pattern of oceanic heating and amounts to almost $15 \mathrm{~W} \mathrm{~m}^{-2}$. In the remaining ocean basins the relationship is less clear. According to the VIZY and COOK (2001) mechanism, this process can only lead to rising precipitation over land, when the moisture-enriched air masses move into West Africa, because atmospheric subsidence is still prevailing over the tropical Atlantic. In turn, moist convection over the southernmost part of West Africa requires surface-wind convergence in the lower troposphere. Indeed, Fig. 15 indicates that surface wind convergence intensifies over the Gulf of Guinea and the southernmost Guinean Coast region, when the tropical Atlantic SST is increased. Thus, in a positive feedback loop the southwesterly monsoon flow is enhanced, maintaining the advection of moist air masses into coastal West Africa. However, to the same extent the northeasterly Harmattan is strengthening, transporting dry air masses over the Sahel and Sudan Zone. This dipole response of West African rainfall to SST changes has also been reported by VIZY and COOK (2001) as well as PAETH and STUCK (2004).

Conclusively, the interannual monsoon variability is related to coherent changes in Atlantic SSTs and in the large-scale upper-tropospheric circulation, which both induce an enhanced continental-scale moisture advection over West Africa. The SST changes trigger the mechanism suggested by VIZY and COOK (2001), where warmer Gulf of Guinea SSTs induce stronger surface wind convergence in the Guinea Coast region and abundant rainfall over the southern part of West Africa. The modification of the TEJ/STJ leads to more humid atmospheric conditions throughout northern Africa and possibly to changes in the triggering and behavior of AEWs. Of course, this large-scale response is still accompanied by changes in land use and vegetation cover, which could not be addressed by this model experiment. Regional SST anomalies also affect precipitation over Morocco and East Africa (LATIF et al., 1999; RodRIGUEZ-FONSECA and DE CASTRO, 2002) but the structure of the associated SST variations in the regional model is smaller-scale than in terms of the West African monsoon system (not shown).

\section{Conclusions}

In our work, key factors of interannual rainfall variability related to the West African monsoon were examined. A regional atmospheric climate model has been used to create a 25-year simulation of North African climate from 1979-2003. The synoptic-scale regional climate model REMO, which has originally been designed for applications in the extratropics, has successfully proved its applicability for low latitudes, after adjusting a small number of parameters to the particular requirements of tropical weather and climate.

In the first part, the 25-year integration of the regional atmospheric model REMO has been evaluated by comparison with observational data. It has been found that the simulated mean climate is in sufficient agreement with observations in order to study the mechanisms of interannual variability in the West African monsoon region. A major deficiency of the regional model consists of the systematic underestimation of subsaharan rainfall. Simulated precipitation over Northwest Africa and the Mediterranean region, which is more affected by largescale circulation than by local feedbacks, is very close to real climate as well as the overall distribution and seasonality of rainfall in the entire model domain.

Although the regional model is forced by 6-hourly boundary data, rainfall events in the inner model domain do not exactly coincide with observed rainfall events. If a spatial or temporal aggregation is undertaken, the correlation with observational data increases. Although the mean state of the model atmosphere and its longerterm variability is in good agreement with the real climate, statistical properties like regional means, temporal means or higher order moments of probability distributions of simulated precipitation should be used for certain follow-up studies, like for instance hydrological modeling. The fact that smaller-scale structures of simulated rainfall are nearly chaotic (and do not depend on the forcing data) indicates that the regional model develops its own, smaller-scale variability. This is a necessary property of a regional atmospheric model. The model data can not be used for case studies of certain observed rainfall events, but daily values and individual grid points can still be used for various applications, which require that climatological characteristics of climate, including mean and variability, are reasonably reproduced (LEBEL et al., 2000). This is particularly valuable in regions, which are earmarked by low station density like for instance northwestern Africa. In general, the regional model provides more skill in subtropical and extratropical regions, where rainfall formation and cloud processes are more related to large-scale circulation than to local feedbacks with the land surface. For follow-up applications, a statistical correction model has been developed to adjust simulated subsarahan rainfall to the observed characteristics, while maintaining consistency with the simulated dynamics. This is particularly promising in REMO, since the dynamical compo- 
nents of African climate are reproduced in a reliable way and African rainfall is closely tied to atmospheric circulation (LONG et al., 2000; Los et al., 2001).

The second part of this study was dedicated to the examination of interannual rainfall variability in the West African monsoon region. The composites of wet and dry summer monsoon seasons obtained from modeled and observational data are similar. Simulated interannual variability is largely in-phase with the observations, but the amplitudes are systematically underestimated, possibly due to the missing interactions with land cover (ZENG et al., 1999, SCHNITZLER et al., 2001). The search for the mechanisms, which are responsible for interannual variations of monsoonal rainfall over the Guinean Coast region, has revealed that West African monsoon variability is linked to both large-scale atmospheric circulation changes and SST variations in the tropical Atlantic and Indian Oceans. A relatively warm pool in the tropical Atlantic implies enhanced latent heat fluxes into the atmosphere and intensifies surface wind convergence and rainfall off and over the Guinean Coast monsoon area. Thus, the long-term experiment with REMO gives support to the theoretical mechanism suggested by VIZY and COOK (2001). This mechanism is accompanied by changes in the dynamical behavior of the TEJ and the STJ.

Compared with existing observational and model data sets for West Africa, this regional climate modeling study has several important advantages and perspectives: (1) A long-term climatology of African climate with mostly realistic boundary conditions and high spatial resolution is available now over a large area. This is of great relevance to hydrological and climatological studies in regions with sparse data coverage and may help to improve our knowledge of the mechanisms and processes, which govern climate variability in the low latitudes. (2) The data can be considered to be fully consistent in a physical-dynamical sense down to the synoptic scale. (3) Due to the ability of REMO to simulate West African climatic features, a tool is at hand now to carry out further sensitivity studies with respect to the key factors in African climate, like land degradation and greenhouse warming (PAETH, 2004). In addition, it can be used for predictions of future climate anomalies at seasonal to decadal time scales, according to the suggestions by DESANKER and JUSTICE (2001) as well as JENKINS et al. (2002).

A basic model failure is presented by the underestimation of the amount and the interannual variations of subsaharan precipitation. Various modifications in the convection scheme have not been successful in reducing the model error so far. Other regional climate model applications in West Africa have experienced similar problems (GALLÉE et al., 2004; VIZY and COOK, 2002), albeit of lower amplitude. It is likely that the enhanced gradient over and off the Guinean Coast region is a function of the grid point representation of orographic elevation in combination with an exaggerated sensitivity of the Tiedtke convection scheme. The missing feedback with vegetation may also contribute to the insufficient formation of rainfall over southern West Africa (ZENG et al., 1999; ZENG and NEELIN, 2000). In order to extend the study towards the assessment of land use changes, the implementation of a dynamical vegetation model in REMO, including anthropogenic changes, is intended.

\section{Acknowledgements}

This work was supported by the German Federal Ministry of Education and Research (BMBF) under grant No. 07 GWK 02 and by the Ministry of Education, Science and Research (MSWF) of the Federal State of Northrhine-Westfalia under grant No. 223-21200200. We thank Reinhard HAGENBROCK and Andreas FinK for making the CRU and IRD data available to us. Thanks to Andreas Hense, Alice KAPALA and Clemens SIMMER for many instructive and helpful discussions. We also thank two anonymous Reviewers for their helpful and constructive suggestions, improving the readability of the paper.

\section{References}

BADER, J., M. LATIF, 2003: The impact of decadal-scale Indian Ocean sea surface temperature anomalies on Sahelian rainfall and the North Atlantic Oscillation. - Geophys. Res. Let. 30, 10.1029/2003GL018426.

BENSON, C., E.J. Clay, 1998: The impact of drought on subSaharan economies. - World Bank Tech Paper, 401, World Bank, Washingtion DC.

Bounoua, L., G.J. Collatz, S.O. Los, P.J. Sellers, D.A. DAZLICH, C.J. TUCKER, D.A. RANDALL, 2000: Sensitivity of climate to changes in NDVI. - J. Climate 13, 22772292.

Chang, P., R. Saravanan, L. Ji, G.C. Hegerl, 2000: The effect of local sea surface temperature on atmopsheric circulation over the tropical Atlantic sector. - J. Climate 13, 2195-2216.

CLARK, D.B., Y. XUE, R.J. HARding, P.J. VAldes, 2001: Modeling the impact of land surface degradation on the climate of tropical North Africa. - J. Climate 14, 1809-1822.

CoOK, K.H., 1999: Generation of the African easterly jet and its role in determining West African precipitation. - J. Climate 12,1165-1184.

CULlen, H.M., P.B. DE Menocal, 2000: North Atlantic influence on Tigris-Euphrates streamflow. - Int. J. Climatol. 20, 853-863.

DESANKER, V. and C.O. JUSTICE, 2001: Africa and global climate change: Critical issues and suggestions for further research and integrated assessment modeling. - Climate Res. 17, 93-103.

Diedhiou, A., S. Janicot, A. Viltard, P. DE FÉlice, 2001: Composite patterns of easterly wave disturbances over West Africa and the tropical Atlantic: A climatology from the 1979-95 NCEP/NCAR reanalyses. - Climate Dyn. 18, 241-253. 
DouVille, H., 2002: Influence of soil moisture on the Asian and African monsoons. Part II: Interannual variability. - J. Climate 15, 701-720.

DOUVILlE, H., F. CHAUVIN, 2000: Relevance of soil moisture for seasonal climate predictions: A preliminary study. - Climate Dyn. 16, 719-736.

Druyan, L.M., M.B. FulakezA, W. Thiaw, 2000: Regional model simulations of African wave disturbances. J. Geophys. Res. 105, 7231-7255.

ENFIELD, D.B., A.M. Mestas-Nuñez, D.A. MAYER, L. CiD-SERrANo, 1999: How ubiquitous is the dipole relationship in tropical Atlantic sea surface temperature? - J. Geophys. Res. 104, 7841-7848.

GAllée, H., W. Moufouma-OKia, P. Bechtold, O. Brasseur, I. Dupays, P. Marbaix, C. Messager, R. RAMEL, T. LEBEL, 2004: A high-resolution simulazion of a West African rainy season using a regional climate mode. - J. Geophys. Res. 109, 10.1029/2003JD004020.

Garric, G., H. Douville, M. DÉQué, 2002: Prospects for improved seasonal predictions of monsoon precipitation over Sahel. - Int. J. Climatol. 22, 331-345.

Giannini, A., P. SARAVAnan, P. Chang, 2003: Oceanic forcing of Sahel rainfall on interannual to interdecadal time scales. - Science 302, 1027-1030.

Gibson, R., P. Kallberg, S. Uppala, A. Hernandez, A. Nomura, E. Serrano, 1997: ERA description. ReAnalysis Project Report Series No. 1, European Centre for Medium-Range Weather Forecasts (ECMWF). Reading. UK.

GRIST, J.P., 2002: Easterly waves over Africa: The seasonal cycle and contrasts between wet and dry years. - Mon. Wea. Rev. 130, 197-211.

GRIST, J.P., S.E. NiChOLSON, 2001: A study of the dynamic factors influencing the rainfall variability in the West African Sahel. - J. Climate 14, 1337-1359.

Hagemann, S., M. Botzet, L. DüMenil, B. MachenHAUER, 1999: Derivation of global GCM boundary conditions from $1 \mathrm{~km}$ land use satellite data. - Max-Planck-Inst. f. Meteor., Report No. 289, Hamburg.

HASTENRATH, S., 2000: Interannual and longer term variability of upper-air circulation over the tropical Atlantic and West Africa in boreal summer. - Int. J. Climatol. 20, 14151430 .

HonG, S.-Y., H.-L. PAN, 2000: Impact of soil moisture anomalies on seasonal, summertime circulation over North America in a regional climate model. - J. Geophys. Res. 105, 29625-29634.

Hulme, M., R. Doherty, T. NGara, M. New, D. Lister, 2001: African climate change: 1900-2100. - Clim. Res. 17, 145-168.

JACOB, D., 2001: A note to the simulation of the annual and interannual variability of the water budget over the Baltic Sea drainage basin. - Meteor. Atmos. Phys. 77, 61-74.

JACOB, D., B.J.J.M. VAN DEN HURK, U. ANDRAE, G. ELGERED, C. ForTelius, L.P. GRAHAM, S.D. JACKSON, U. Karstens, C. Koepken, R. Lindau, R. Podzun, B. Rockel, F. Rubel, B.H. SAss, R. Smith, X. YAng, 2001: A comprehensive model intercomparison study investigating the water budget during the PIDCAP period. Meteor. Atmos. Phys. 77, 19-44.
Janicot, S., S. Trzaska, I. Poccard, 2001: Summer Sahel-ENSO teleconnection and decadal time scale SST variations. - Clim. Dyn. 18, 303-320.

Jenkins, G.S., A. KAMGA, A. GARBA, A. Diedhiou, V. MORRIS, E. JOSEPH, 2002: Investigating the West African climate system using global/regional climate models. Bull. Amer. Meteor. Soc. 83, 583-595.

LATIF, M., D. Dommenget, M. DimA, A. Groetzner, 1999: The role of Indian Ocean sea surface temperature in forcing East African rainfall anomalies during DecemberJanuary 1997/1998. - J. Climate 12, 3497-3504.

LE BARBÉ, L., T. LeBEL, D. TAPSOBA, 2002: Rainfall variability in West Africa during the years 1950-90. - J. Climate 15, 187-202.

LEBEl, T., F. Delclaux, L. Le BArbé, J. Polcher, 2000: From GCM scales to hydrological scales: Rainfall variability in West Africa. - Stochastic and Environmental Research and Risk Assessment 14, 275-295.

LIM, H.-S., C.-H. Ho, 2000: Comparison of tropical rainfall between the observed GPCP data and the assimilation products of ECMWF, NCEP/NCAR, and NASA-GEOS-1. - J. Met. Soc. Japan 78, 661-672.

Long, M., D. EnTEKhABI, S.E. Nicholson, 2000: Interannual variability in rainfall, water vapor flux, and vertical motion over West Africa. - J. Climate 13, 3827-3841.

Los, S.O., G.J. Collatz, L. BounouA, P.J. Sellers, C.J. TUCKER, 2001: Global interannual variations in sea surface temperature and land surface vegetation, air temperature, and precipitation. - J. Climate 14, 1535-1576.

MAJEWSKI, D., 1991: The Europa-Modell of the Deutscher Wetterdienst. - Seminar Proceedings ECMWF 2, 147-191.

MEARNS, L.O., I. BOGARDI, F. GIORGI, I. MATYASOVSZKY, M. PALECKI, 1999: Comparison of climate change scenarios generated from regional climate model experiments and statistical downsclaing. - J. Geophys. Res. 104, 6603-6621.

MO, K.C., W.M. THIAW, 2002: Ensemble canonical correlation prediction of precipitation over the Sahel. - Geophys. Res. Let. 29, 10.1029/2002GL015075.

NeW, M., M. Hulme, P. Jones, 2000: Representing twentieth-century space-time climate variability. Part II: Development of 1901-96 monthly grids of terrestrial surface climate. - J. Climate 13, 2217-2238.

NiCHOLSON, S.E., 2001: Climatic and enviromental change in Africa during the last two centuries. - Climate Res. 17, 123-144.

NiCHOLSON, S.E., J.P. GRIST, 2001: A conceptual model for understanding rainfall variability in the West African Sahel on interannual and interdecadal timescales. - Int. J. Climatol. 21, 1733-1757.

NiCHOLSON, S.E., J.C. Selato, 2000: The influence of La Niña on African rainfall. - Int. J. Climatol. 20, 1761-1776.

Nicholson, S.E., B. Some, B. Kone, 2000: An analysis of recent rainfall conditions in West Africa, including the rainy season of the $1997 \mathrm{El}$ Niño and the 1998 La Niña years. J. Climate 13, 2628-2640.

PAETH, H., 2004: Key factors in African climate change evaluated by a regional climate model. - Erdkunde 58, 290315.

Paeth, H., A. Hense, 2003: Seasonal forecast of subsahelian rainfall using cross validated model output statistics. - Meteorol. Z. 12, 157-173. 
-, - 2004: SST versus climate change signals in West African rainfall: 20th century variations and future projections. - Climate Change 65, 179-208.

PAeTh, H., J. STUCK, 2004: The West African dipole in rainfall and its forcing mechanisms in global and regional climate models. - Mausam 55, 561-582.

PARKER, D.E., L.V. AlEXANDER, 2002: Global and regional climate in 2001. - Weather 57, 328-340.

PocCARD, I., S. JANICOT, P. CAMBERLIN, 2000: Comparison of rainfall structures between NCEP/NCAR reanalyses and observed data over tropical Africa. - Clim. Dyn. 16, 897-915.

REDElsperger, J.-L., A. Diongue, A. Diedhiou, J.-P. Ceron, M. Diop, J.-F. Gueremy, J.-P. LAFore, 2002 Multi-scale description of a Sahelian synoptic weather system representative of the West African monsoon. - Quart. J. Roy. Met. Soc. 128, 1229-1257.

RoDriguez-FonseCA, B., M. DE CAStro, 2002: On the connection between winter anomalous precipitation in the Iberian Peninsula and North West Africa and the summer subtropical Atlantic sea surface temperature. - Geophys. Res. Let. 29, 10.1029/2001GL014421.

Roeckner, E., K. Arpe, L. Bengtsson, M. Christoph, M. Claussen, L. Dümenil, M. Esch, M. Giorgetta, U. SCHLESE, U. SCHulzweIdA, 1996: The atmospheric general circulation model ECHAM-4: Model description and simulation of present-day climate. - Max-Planck-Inst. f. Meteor., Report No. 218, Hamburg.

,,-- 2001 : African monsoons. Part 1: Climatological structure and circulation. - Mausam 52, 479-510.

SAHA, K.R., S. SAHA, 2002: African monsoons. Part 2: Synoptic-scale wave disturbances in the intertropical convergence zone over North Africa. - Mausam 53, 197-214.

Schnitzler, K.-G.. W. Knorr, M. LAtif, J. BAder, N. ZENG, 2001: Vegetation feedback on Sahelian rainfall vari- ability in a coupled climate land-vegetation model. - MaxPlanck-Inst. f. Meteor., Report No. 329, 13 pp.

SEMAZZI, F.H.M., Y. SonG, 2001: A GCM study of climate change induced by deforestation in Africa. - Climate Res. 17, 169-182.

STEPHEnson, D.B., 2000: Use of the "Odds Ratio" for diagnosing forecast skill. - Weather and Forecasting 15, 221232.

Thorncroft, C., K. Hodges, 2001: African Easterly wave variability and its response to Atlantic tropical cyclone activity. - J. Climate 14, 1166-1179.

TiEdTKe, M., 1989: A comprehensive mass flux scheme for cumulus parameterization in large scale models. - Mon. Wea. Rev. 117, 1779-1800.

VIZY, E.K., K.H. COOK, 2001: Mechanisms by which Gulf of Guinea and Eastern North Atlantic sea surface temperature anomalies can influence African rainfall. - J. Climate 14, 795-821.

,,-- 2002 : Development and application of a meso-scale climate model for the tropics: Influence of sea surface temperature anomalies on the West African monsoon.- J. Geophys. Res. 107, 10.1029/2001JD000686.

WAng, G., A.B. Eltahir, 2000: Ecosystem dynamics and the Sahel drought. - Geophys. Res. Let. 27, 795-798.

WILKS, D.S., 1995: Statistical methods in the atmospheric sciences. - San Diego, Academic Press, 467 pp.

ZENG, N., J.D. NEELIN, 2000: The role of vegetationclimate interaction and interannual variability in shaping the African Savanna. - J. Climate 13, 2665-2670.

ZENG, N., J.D. NeElin, K.-M. LAU, C.J. TuCKER, 1999: Enhancement of interdecadal climate variability in the Sahel by vegetation interaction. - Science 286, 1537-1540.

Zolina, O., A. Kapala, C. Simmer, S. Gulev, 2004: Analysis of extreme precipitation over Europe from different reanalyses: A comparative assessment. - Global and Planetary Change 44, 129-161. 